\title{
ZASTOSOWANIE ANALIZY KORESPONDENCJI DO KLASYFIKACJI MATERIAŁÓW Z PÓŹNEJ EPOKI BRĄZU NA PRZYKŁADZIE OBIEKTÓW FUNERALNYCH Z POLSKI POLUDNIOWO-WSCHODNIEJ ${ }^{1}$
}

\author{
APPLICATION OF THE CORRESPONDENCE ANALYSIS TO THE \\ CLASSIFICATION OF MATERIALS FROM THE LATER BRONZE \\ AGE ON THE EXAMPLE OF FUNERAL INVENTORY FROM \\ SOUTH-EAST POLAND
}

\author{
Wojciech Rajpold \\ https://orcid.org/0000-0001-9404-6701 \\ Instytut Archeologii Uniwersytetu Rzeszowskiego, ul. Moniuszki 10, 35-015 Rzeszów \\ Wojtek-Rajpold@wp.pl
}

\begin{abstract}
It is truism to say that for an archaeologist the question of chronology is particularly important. In relation to Tarnobrzeg Lusatian Culture, this topic was frequently raised, which in the case of its early and late stages gave satisfactory results. There are numerous determinants of these phases, and they can also be divided into smaller periodical stages. The dynamics of change is well understood. However, phase II is far more problematic. Basically, it is represented by one type of vessel. In addition, the 150-200 year phase is very compact in terms of inventory and it is almost impossible to identify older or younger materials. The problem of its decline also needs to be emphasized, where when treated through the prism of the San River style as it usually is, it should be prolonged to HaD. The author, using the correspondence board, tries to indicate materials which can be related to the older and younger episode of the second phase of Tarnobrzeg Lusatian Culture.
\end{abstract}

KEY WORDS: correspondence analysis, periodization, Nadsan stylistics, Tarnobrzeg Lusatian culture, funeral archeology, statistics

${ }^{1}$ Projekt został sfinansowany ze środków Narodowego Centrum Nauki przyznanych na podstawie decyzji numer DEC- 2016/23/N/HS3/00666. 
Nie trzeba nikogo przekonywać, że temat chronologii jest w archeologii niezwykle istotny. Dobry system periodyzacji umożliwia umieszczenie na osi czasu procesów kulturowych zachodzących w pradziejach, co ułatwia ich zrozumienie (Czopek, 2009, s. 20). W przypadku omawianego tarnobrzeskiego wariantu kultury kręgu pól popielnicowych ${ }^{2}$ powstały liczne opracowania dotyczące tej tematyki. W pierwszej kolejności należy wymienić prace M. Gedla $(1962,1970)$ i K. Moskwy (1976). Badacze ci zaproponowali 3-fazowy system periodyzacyjny. Wskazując materialne wyznaczniki (materiały ceramiczne oraz metalowe) kolejnych faz, dokonali próby zdefiniowania wpływów zewnętrznych, np. liczne zabytki o proweniencji wschodniej w późnej fazie rozwoju TKŁ oraz procesów zachodzących wewnątrz, np. zmiany obrządku pogrzebowego (groby szkieletowe we wczesnej fazie rozwoju TKŁ). Podział ten nie wyczerpywał jednak podjętej problematyki, co zostało skomentowane przez B. Gedigę w 1986 roku podczas konferencji poświęconej TKŁ. Badacz ten wyraził pogląd, że system ten można odnosić do wszystkich zjawisk kulturowych (gdzie każde ma początek, środek oraz koniec), nie można go więc traktować jako wewnętrzną periodyzację rozwoju (Gediga, 1989, s. 17-18). Nieco później, po wspomnianej konferencji, J. Chochorowski zaproponował dla najwcześniejszego okresu rozwoju TKL podział na trzy horyzonty A (BC2-BD), B (HaA2-HaB1) i C (HaB2-HaB3) oraz materiały pośrednie $\mathrm{A} / \mathrm{B}(\mathrm{HaA} 1)$ i $\mathrm{B} / \mathrm{C}(\mathrm{HaB} 1 / \mathrm{HaB} 2)$. Okres środkowy wg tej chronologii miał przypadać na HaB3 i HaC, a późny HaD i LtB (za: Czopek, 2009, s. 22). Dalsze badania prowadzone na cmentarzyskach i osadach TKŁ pozwoliły doprecyzować ten system, m.in. nie potwierdzono datowania TKŁ na BC2 (Blajer, Czopek, Kostek, 1991). Dokonano również przesunięcia początków III fazy na $\mathrm{HaC}$ i rozbito ją na dwie podfazy - starszą z materiałami scytyjskimi i naczyniami wazowatymi oraz młodszą z garnkami jajowatymi (Czopek, 1989, s. 249). Kolejne analizy prowadzone na cmentarzyskach i osadach TKŁ przynosiły dalsze korekty. Kluczowe okazały się badania na Grodzisku Dolnym, stan. 1, pow. łańcucki i w Chodaczowie, stan. 2, które pozwoliły na podzielenie tradycyjnie pojmowanej fazy I na mniejsze stadia (Czopek, 1996, s. 66-77). Także daty C14 oraz analizy stratygraficzne grobów z Pysznicy stan. 1 pow. stalowowolski dały podstawy do kolejnych uściśleń chronologii (Czopek, 2001, s. 184). Na zakończenie tej części warto również wspomnieć o artykule M. S. Przybyły (2003), który stanowił próbę statystycznego uporządkowania materiałów ceramicznych TKŁ.

Aktualnie na podstawie dotychczasowych ustaleń (Czopek, Trybała-Zawiślak, 2015) można zaprezentować następujący podział:

${ }^{2} \mathrm{~W}$ dalszej części będziemy wykorzystywać skrót TKŁ - od tarnobrzeska kultura łużycka. Jest to termin specyficzny dla badaczy z Polski południowo-wschodniej dla określenia lokalnej grupy z kręgu pól popielnicowych rozwijającej się w międzyrzeczu Wisłoki, Wisły i Sanu od XIII do IV/III stulecia p.n.e. $\mathrm{O}$ jej wyjątkowym charakterze zadecydowały wpływy (zwłaszcza w początkach rozwoju) z południa (kultura gava-holichrady) i (w późnej fazie) południowego-wschodu (głównie scytyjskie i scytotrackie). Po raz pierwszy terminu tego użył Jan Dąbrowski w swojej pracy z 1980 roku poświęconej zróżnicowaniu wewnętrznemu kultury łużyckiej. 
faza I - od okresu BD/HaA1 do HaB3 (XIII/XII-IX w. p.n.e.), wydziela się tu podfazy A (I1) i B (I2-3);

faza II - od HaB3/HaC do HaC/D (koniec IX - poł. VII w. p.n.e.);

faza III - od HaD do LtB /starszego okresu przedrzymskiego/ (poł. VII IV w. p.n.e), z dwiema podfazami III1 i III2.

Zarówno dla I, jak i III fazy możemy wyróżnić wyraźne podfazy oparte na zróżnicowaniu stylistyki naczyń. W ich kontekście, jako bardziej zwarta stylistycznie, jawi się faza II, w przypadku której bardzo trudno wychwycić jest jakiekolwiek zmiany form czy ornamentyki. W dużej mierze jest to efekt traktowania tego okresu jako momentu regresu kulturowego i osłabienia kontaktów zewnętrznych (Moskwa, 1982, s. 311). Jest to także wynik postrzegania tego etapu przez pryzmat „stylistyki nadsańskiej" do tego stopnia, że stała się ona wręcz wyznacznikiem tej fazy (Czopek, 2001, s. 167). Jak bardzo jest to mylne stwierdzenie, pokazuje przykład cmentarzyska w Obojnie, pow. stalowowolski, gdzie w grobie z wazą nadsańską znaleziono kolczyk gwoździowaty (Szarek-Waszkowska, 1973), będący niepodważalnym wyznacznikiem późnej fazy rozwoju TKŁ. Także analizy dotyczące cmentarzyska w Bachórzu-Chodorówce, stan. 1, pow. rzeszowski (Gedl, 1994, s. 57) pokazały zupełnie inny rytm zmian. W czasie, gdy na północy rozwija się „,stylistyka nadsańska", na południu mamy do czynienia z kontynuacją zapoczątkowanych wcześniej nurtów stylistycznych (Gawlik, Przybyła, 2005, s. 315). Ważny jest też przypadek cmentarzyska w Pysznicy, który wskazuje na równoczasowość występowania stylistyki nadsańskiej z trendem „ogólnołużyckim” i ich paralelny rozwój (Czopek, 2001, s. 184). Stylistyka ta nie może być więc w żadnym razie jedynym wyznacznikiem środkowego okresu rozwoju TKŁ, co więcej, część łączonych z nią materiałów należy przypisać już do HaD. To właśnie schyłek fazy II stanowi daleko bardziej problematyczną kwestię niż jej początki (Trybała-Zawiślak, 2019, s. 87) i ta kwestia obok „stylistyki nadsańskiej” będzie stanowić główny temat naszych rozważań.

Na początku warto wyjaśnić, co rozumiemy przez stwierdzenie „stylistyka nadsańska" i pod stosowanym w opozycji do niego terminem „stylistyka ogólnołużycka". Obie nazwy zostały wprowadzone przez S. Czopka (Czopek, 1996, s. 117; 2001, s. 141) w celu zdefiniowania większych zespołów naczyń o określonych walorach stylistycznych i taksonotwórczych. Stylistykę nadsańską zwykło się definiować przez pryzmat waz i dzbanów nadsańskich oraz tzw. mis zbydniowskich o bardzo charakterystycznej ornamentyce. Terminy te od lat funkcjonują w literaturze i dokładne ich opisywanie wydaje się zbędne. Tym bardziej że „stylistyka nadsańska” stała się podstawą wielu analiz, a nawet rozprawy doktorskiej (Ormian, 2008). Praca ta pozwoliła podzielić stylistykę nadsańską na 4 etapy. Pierwszy z nich tzw. „proto-nadsański” (faza I1 w rozwoju TKŁ) charakteryzował się szerokootworowymi wazami o lejkowatej szyjce często z dwoma taśmowatymi uchami i ornamentyką rytą powyżej załomu brzuśca, a także rożkowatymi guzkami (Ormian, 2008, s. 249). W kolejnym etapie, tj. fazie przedklasycznej (faza I2-3), pojawiły się misy zbydniowskie i bardziej rozbudowane wątki ornamentacyjne. Jednak w tym przypadku jedynym aspektem 
datowania na tę konkretną fazę jest współwystępowanie z innymi typami naczyń. Większość styli powstałych w tym okresie rozwija się także w kolejnym (Ormian, 2008, s. 252-254). Fazę „klasyczną” (II faza) miało reprezentować największe zróżnicowanie form naczyń oraz sposobów ornamentyki. W zasadzie notujemy tu wszystkie elementy typowe dla tej stylistyki (Ormian, 2008, s. 256-257). Natomiast ostatni z etapów, tzw. postklasyczny, „stylistyka nadsańska przekształcona” (początek III fazy) to moment ubożenia ornamentyki oraz stopniowego upodobniania się „stylistyki nadsańskiej” do trendu „ogólnołużyckiego” (Ormian, 2008, s. 264).

Należy podkreślić, że w zaprezentowanym wyżej podziale w przypadku materiałów z fazy klasycznej, które miałyby w całości przypadać na II fazę, nie notujemy żadnego rozwarstwienia. Znamienny jest również problem materiałów najmłodszych, które nachodzą na III fazę rozwoju TKŁ, potwierdzając tym samym, że stylistyka ta nie może być bezkrytycznie brana pod uwagę jako podstawowy wyznacznik fazy II.

Głównym zadaniem prezentowanej pracy było sprawdzenie, czy za pomocą analizy korespondencji materiały tradycyjnie pojmowanej II fazy wykazują zróżnicowanie formalne, które może być podstawą wydzielenia mniejszych jednostek klasyfikacji tej stylistyki. Metoda ta pozwala na graficzną prezentację relacji między badanymi cechami. Podkreślenia wymaga to, że prezentowane w tym miejscu narzędzie analityczne wykorzystywano $\mathrm{w}$ wielu pracach dotyczących periodyzacji. Jako przykład można wymienić pracę Ł. Mrówki (2011), w której przy użyciu analizy korespondencji badano rozwój stylistyki naczyń z cmentarzyska w Kietrzu. Metoda ta posłużyła także niedawno przy tworzeniu chronologii materiałów kultury trzcinieckiej z południowo-wschodniej Polski (Adamik-Proksa, 2019, s. 64). Warto również wspomnieć o wykorzystaniu jej przy próbie zbadania zależności między konkretnym taksonem a stylistyką nadsańską i ogólnołużyckim trendem (Trybała-Zawiślak, 2019, s. 101-105). Metoda ta znajduje więc zastosowanie w archeologii, a jej znaczenia dla analiz chronologicznych nie można nie doceniać.

Ostatnim aspektem, który należy poruszyć, jest kwestia zakresu terytorialnego i rzeczowego analiz. Jak wcześniej wspomniano, „stylistyka nadsańska” była ograniczona do północnej części obszaru zajmowanego przez TKŁ (ryc. 1). Na tym terenie udokumentowano do tej pory 26 stanowisk z ceramiką wykonaną w tym stylu. Ich wartość poznawcza jest bardzo różna (od pojedynczych fragmentów naczyń do kilkuset urn), dlatego zdecydowano się ograniczyć analizy do 3 nekropolii, które zawierały największą ilość materiałów o stylistyce nadsańskiej. Należą do nich: Pysznica, Zbydniów stan. 1 pow. stalowowolski (Moskwa, 1979) i Furmany stan. 1, pow. tarnobrzeski (Ormian, 1998). Chronologia tych cmentarzysk w całości mieści się w ramach II fazy rozwoju TKŁ. W przypadku Pysznicy notujemy dodatkowo materiały z początków późnej fazy, Furmany miały się rozwijać przez wszystkie trzy fazy, a chronologia Zbydniowa była ograniczona do II fazy (Czopek, 2006, s. 102-103, tab. 1). Zaprezentowana tu baza źródłowa reprezentuje więc cały przekrój stylistyki nadsańskiej. 


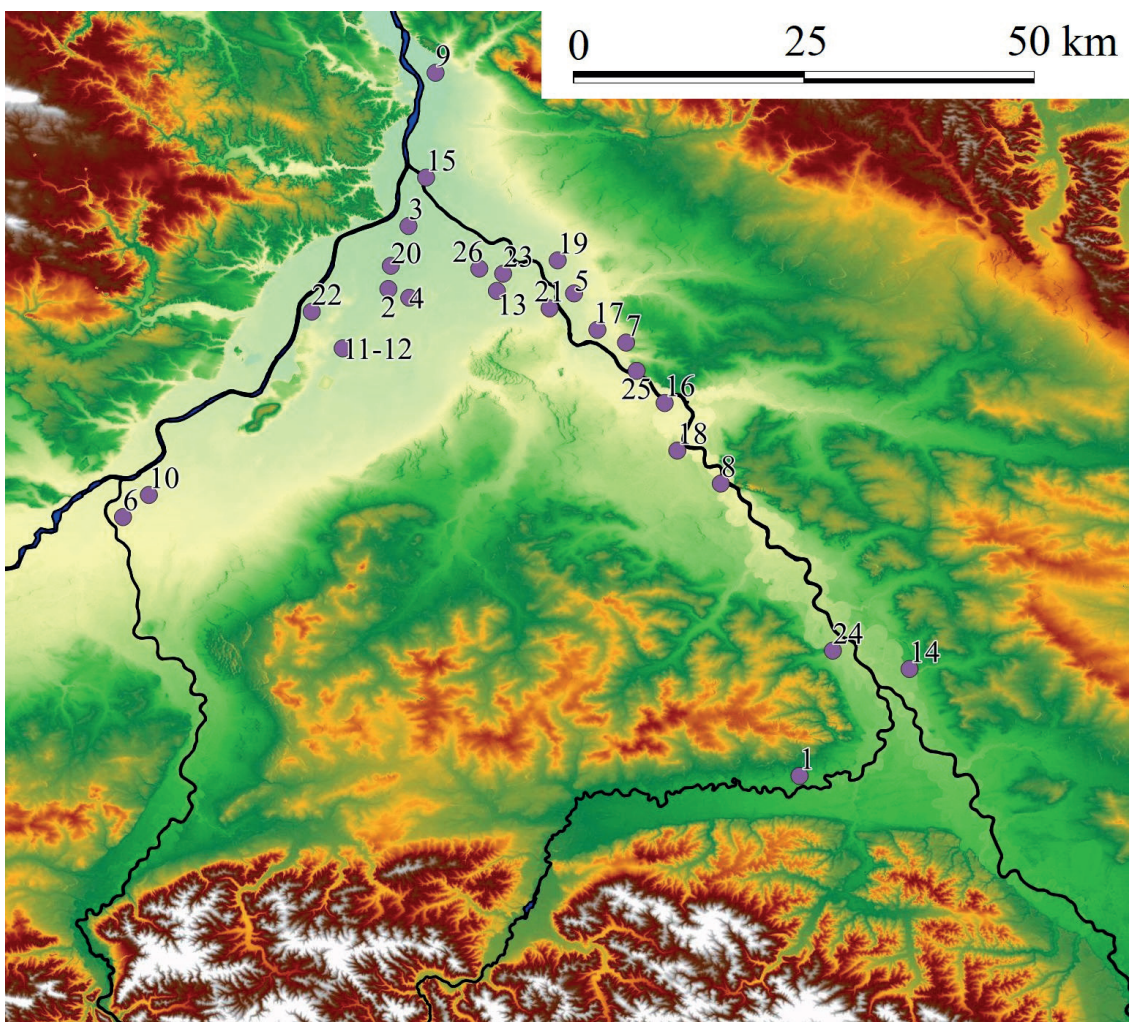

Ryc. 1. Stanowiska z materiałami o stylistyce nadsańskiej (za K. Trybała-Zawiślak, 2019, s. 81, ryc. 3.1) (1. Budy Łańcuckie, stan. 1, pow. łańcucki; 2. Furmany, stan. 1, pow. tarnobrzeski, 3. Gorzyce, stan. 1, pow. tarnobrzeski; 4. Grębów, stan. 1, pow. tarnobrzeski; 5. Jastkowice, stan. 1, pow. stalowowolski; 6. Kębłów, stan. 4, pow. mielecki; 7. Kłyżów, stan. 2, pow. stalowowolski; 8. Kopki, stan. 3, pow. niżański; 9. Kosin, stan. II, pow. kraśnicki; 10. Krzemienica, stan. 1, pow. mielecki; 11-12. Tarnobrzeg-Mokrzyszów, stan. 1 i 2, pow. loco; 13. Obojna, stan.1, pow. stalowowolski; 14. Paluchy, stan. 1, pow. przeworski; 15. Pniów, stan.1, pow. tarnobrzeski; 16. Przędzel, stan. 5, pow. niżański; 17. Pysznica, stan. 1 pow. stalowowolski; 18. Rudnik n. Sanem, stan. 10, pow. stalowowolski; 19. Rzeczyca Długa, stan. 5, pow. stalowowolski; 20. Sokolniki, stan. 1, pow. tarnobrzeski; 21. Stalowa Wola-Rozwadów, stan.?, pow. loco; 22. Tarnobrzeg-Dzików, stan. 2, pow. loco; 23. Turbia, stan. „Dąbrówka”, pow. stalowowolski; Wierzawice, stan. 22, pow. leżajski; 25. Zarzecze, stan. 1, pow. przeworski; 26. Zbydniów, stan. 1, pow. stalowowolski)

Fig. 1. Sites with materials in the Nadsańska style (after K. Trybała-Zawiślak, 2019, p. 81, fig. 3.1), (1. Budy Łańcuckie, site 1, Łańcucki district; 2. Furmany, site 1, Tarnobrzeski district, 3. Gorzyce, site 1, Tarnobrzeski district; 4. Grębów, site 1, Tarnobrzeski district; 5. Jastkowice, site 1, Stalowowolski district; 6. Kębłów, site 4, Mielecki district; 7. Kłyżów, site 2, Stalowowolski district; 8. Kopki, site 3, Niżański district; 9. Kosin, site II, Kraśnicki district; 10. Krzemienica, site 1, Mielecki district; 11-12. Tarnobrzeg -Mokrzyszów, site 1 and 2, loco area; 13. Obojna, site 1, Stalowowolski district; 14. Paluchy, site 1, Przeworski district; 15. Pniów, site 1, Tarnobrzeski district; 16 Przędzel, site 5, Niżański district, 17. Pysznica, site 1, Stalowowolski district, 18. Rudnik n. Sanem, site 10, Stalowowolski district, 19. Rzeczyca Długa, site 5, Stalowowolski district; 20. Sokolniki, site 1, district Tarnobrzeski; 21. Stalowa Wola-Rozwadów, site?, Site ex-loco; 22. Tarnobrzeg-Dzików, site 2, district ex-loco; 23. Turbia, site „Dąbrówka” , Stalowowolski district; Wierzawice, state. 22, Leżajsk district; 25. Zarzecze, state. 1, Przeworski district; 26 Zbydniów, state. 1, Stalowowolski district) 
Tabela 1. Zestawienie dat absolutnych dla cmentarzyska w Pysznicy (za S. Czopek, 2001, s. 167-173, tab. XVI)

Table 1. List of absolute dates for the cemetery in Pysznica (after S. Czopek, 2001, p. 167-173, table XVI)

\begin{tabular}{|c|c|c|c|c|}
\hline \multirow{2}{*}{$\begin{array}{c}\mathrm{Nr} \\
\text { Gro- } \\
\text { bu }\end{array}$} & \multirow{2}{*}{ Daty } & \multicolumn{2}{|c|}{$\mathrm{Cal} \mathrm{BC}$} & \multirow{2}{*}{ Materiał } \\
\hline & & $68,2 \%(1 \sigma)$ & $95,4 \%(1 \sigma)$ & \\
\hline 1 & 2 & 3 & 4 & 5 \\
\hline 443 & $\begin{array}{l}\text { C14 } \\
2450 \pm 70\end{array}$ & $748(68,2 \%) 416$ & $770(95,4 \%) 406$ & $\begin{array}{l}\text { Popielnica - WND2 ozdobiona pseudusz- } \\
\text { kami w miejscu przejścia szyjki w brzu- } \\
\text { siec, pod krawędzią wylewu rząd otwor- } \\
\text { ków, na brzuścu guzki oraz zakreskowane } \\
\text { trójkąty i czworokąty poprzedzielane } \\
\text { dołkami oraz dołki ujęte pomiędzy piono- } \\
\text { wymi liniami rytymi; pokrywa - mocno } \\
\text { zniszczona, fragmenty profilowanej misy } \\
\text { lub czerpaka; profilowany czerpak półko- } \\
\text { listy, ozdobiony guzkami; brązowy } \\
1,5 \text { zwojowy skręt z okrągłego drutu }\end{array}$ \\
\hline 447 & $\begin{array}{l}\mathrm{C} 14 \\
2480 \pm 70\end{array}$ & $\begin{array}{l}767(66,7 \%) 536 \\
528(1,5 \%) 522\end{array}$ & $782(95,4 \%) 414$ & $\begin{array}{l}\text { Popielnica - niezdobiona WOŁ } 3 \text {; przy- } \\
\text { stawka - czerpak z dnem wgiętym do } \\
\text { środka }\end{array}$ \\
\hline 468 & $\begin{array}{l}\mathrm{C} 14 \\
2560 \pm 70\end{array}$ & $\begin{array}{l}806(28,0 \%) 740 \\
688(8,3 \%) 664 \\
646(31,9 \%) 549\end{array}$ & $835(95,4 \%) 430$ & $\begin{array}{l}\text { Popielnica - WND5 guzki na brzuścu } \\
\text { oraz czworokąty przerywane promienisty- } \\
\text { mi liniami odchodzącymi od pseudouszek } \\
\text { umieszczonych w miejscu przejścia szyjki } \\
\text { w brzusiec; pokrywa - mocno zniszczona } \\
\text { prawdopodobnie misa zbydniowska }\end{array}$ \\
\hline 478 & $\begin{array}{l}\mathrm{C} 14 \\
2310 \pm 70\end{array}$ & $\begin{array}{l}481(8,2 \%) 441 \\
434(34,1 \%) 351 \\
301(25,9 \%) 210\end{array}$ & $\begin{array}{l}745(4,1 \%) 687 \\
665(1,3 \%) 644 \\
552(90,1) 183\end{array}$ & $\begin{array}{l}\text { Popielnica - GARJAJ1 z otworkami pod } \\
\text { krawędzią wylewu chropowacono na całej } \\
\text { powierzchni }\end{array}$ \\
\hline 644 & $\begin{array}{l}\mathrm{C} 14 \\
2400 \pm 70\end{array}$ & $\begin{array}{l}737(13,0 \%) 688 \\
663(4,0 \%) 647 \\
548(51,2 \%) 398 \\
\end{array}$ & $766(95,4 \%) 385$ & $\begin{array}{l}\text { Popielnica - GARTUL1 z guzkami na } \\
\text { szyjce chropowacono na całej powierzchni }\end{array}$ \\
\hline 660 & $\begin{array}{l}\text { C14 } \\
2535 \pm 80\end{array}$ & $\begin{array}{l}800(22,3 \%) 728 \\
716(1,8 \%) 708 \\
694(44,1 \%) 542\end{array}$ & $811(95,4 \%) 415$ & $\begin{array}{l}\text { Popielnica - WOŁ13 z półokrągłym } \\
\text { wcięciem na krawędzi wylewu }\end{array}$ \\
\hline 667 & $\begin{array}{l}\mathrm{C} 14 \\
2465 \pm 70\end{array}$ & $\begin{array}{l}757(21,9 \%) 679 \\
672(44,1 \%) 508 \\
500(2,1 \%) 491 \\
\end{array}$ & $775(95,4 \%) 409$ & $\begin{array}{l}\text { Popielnica - WND4 ozdobiona guzkami } \\
\text { na brzuścu a w miejscu przejścia szyjki } \\
\text { w brzusiec pseudouszka }\end{array}$ \\
\hline 702 & $\begin{array}{l}\mathrm{C} 14 \\
2455 \pm 80\end{array}$ & $\begin{array}{l}751(19,1 \%) 683 \\
668(8,8 \%) 636 \\
626(3,1 \%) 614 \\
592(31,6 \%) 474 \\
462(1,9 \%) 455 \\
445(3,7 \%) 431\end{array}$ & $781(95,4 \%) 404$ & $\begin{array}{l}\text { Popielnica - WOŁ2 } 6 \text { otworki pod krawę- } \\
\text { dzią wylewu, ukośne linie ryte na brzuścu }\end{array}$ \\
\hline
\end{tabular}




\begin{tabular}{|c|c|c|c|c|}
\hline 726 & $\begin{array}{l}\mathrm{C} 14 \\
2380 \pm 70\end{array}$ & $\begin{array}{l}731(10,2 \%) 691 \\
660(2,4 \%) 650 \\
544(55,6 \%) 390\end{array}$ & $\begin{array}{l}769(94,9 \%) 360 \\
271(0,5 \%) 263\end{array}$ & $\begin{array}{l}\text { Popielnica - WOŁ27 ozdobiona na } \\
\text { szyjce dołkami wykonanymi stempelka- } \\
\text { mi, w miejscu przejścia szyjki w brzusiec } \\
\text { dwie poziome linie ryte, poniżej zakresko- } \\
\text { wane trójkąty na największej wydętości } \\
\text { brzuśca rożkowate guzki a pod nimi dwie } \\
\text { głębokie bruzdy }\end{array}$ \\
\hline 729 & $\begin{array}{l}\mathrm{C} 14 \\
2330 \pm 70\end{array}$ & $\begin{array}{l}540(53,3 \%) 353 \\
295(13,9 \%) 229 \\
219(1 \%) 213\end{array}$ & $\begin{array}{l}753(8,6 \%) 682 \\
670(5,0 \%) 612 \\
594(81,8 \%) 201\end{array}$ & $\begin{array}{l}\text { Popielnica - GARJAJ1 chropowacona na } \\
\text { całej powierzchni z plastycznymi listwami } \\
\text { pod krawędzią wylewu i na brzuścu }\end{array}$ \\
\hline 736 & $\begin{array}{l}\mathrm{C} 14 \\
2380 \pm 80\end{array}$ & $\begin{array}{l}742(12,6 \%) 687 \\
665(4,2 \%) 645 \\
550(51,4 \%) 384\end{array}$ & $\begin{array}{l}773(92,1 \%) 357 \\
285(3,3 \%) 235\end{array}$ & $\begin{array}{l}\text { Popielnica - WOŁ } 3 \text { z otworkami pod } \\
\text { krawędzią wylewu }\end{array}$ \\
\hline 468 & $\begin{array}{l}\mathrm{C} 14 \\
2520 \pm 80\end{array}$ & $\begin{array}{l}794(19,8 \%) 727 \\
719(3,2 \%) 705 \\
695(45,2 \%) 541 \\
\end{array}$ & $803(95,4 \%) 416$ & $\begin{array}{l}\text { Inwentarz jw., druga data uzyskana } \\
\text { z kości }\end{array}$ \\
\hline 644 & $\begin{array}{l}\text { C14 } \\
2345 \pm 80\end{array}$ & $\begin{array}{l}731(7,1 \%) 691 \\
660(1,5 \%) 651 \\
544(54,8 \%) 358 \\
281(4,1 \%) 257 \\
242(0,6 \%) 238\end{array}$ & $\begin{array}{l}757(11,4 \%) 679 \\
672(69,3 \%) 347 \\
320(14,7 \%) 206\end{array}$ & $\begin{array}{l}\text { Inwentarz jw., druga data uzyskana } \\
\text { z kości }\end{array}$ \\
\hline 729 & $\begin{array}{l}\text { C14 } \\
2340 \pm 80\end{array}$ & $\begin{array}{l}728(1,9 \%) 717 \\
708(2,4 \%) 694 \\
542(55,3 \%) 357 \\
285(8,6 \%) 235\end{array}$ & $\begin{array}{l}756(10,5 \%) 679 \\
671(6,5 \%) 605 \\
599(61,3 \%) 343 \\
326(17,1 \%) 204\end{array}$ & $\begin{array}{l}\text { Inwentarz jw., druga data uzyskana } \\
\text { z kości }\end{array}$ \\
\hline
\end{tabular}

\section{METODYKA}

Jak wspomniano, analiza korespondencji znajduje szerokie zastosowanie w badaniach dotyczących chronologii. Metoda ta pozwala na określenie struktury powiązań między wierszami i kolumnami w tabeli wielodzielczej (Stanisz, 2007, s. 307-353). Najprościej mówiąc, metoda ta pozwala zbadać relacje między konkretnymi cechami (typ popielnicy i jej ornamentyka) a grobami, z których te przedmioty pochodziły. Dane te przyjmują najczęściej układ skupisk. Jeżeli różnice między analizowanymi cechami są minimalne, algorytm grupuje dane w jedno skupisko. W przypadku większej liczby różnic, graficzna prezentacja danych przybiera postać wieloskupiskową. Natomiast przy dystynkcjach o charakterze zarówno jakościowym, jak i ilościowym (mniejsze lub większe natężenie danej cechy w badanych zbiorach) kształt sinusoidalny. Jest to najbardziej pożądana postać wykresu przy wszystkich studiach z zakresu chronologii, ponieważ poświadcza ona ewolucyjne zmiany zachodzące $\mathrm{w}$ badanym układzie. 


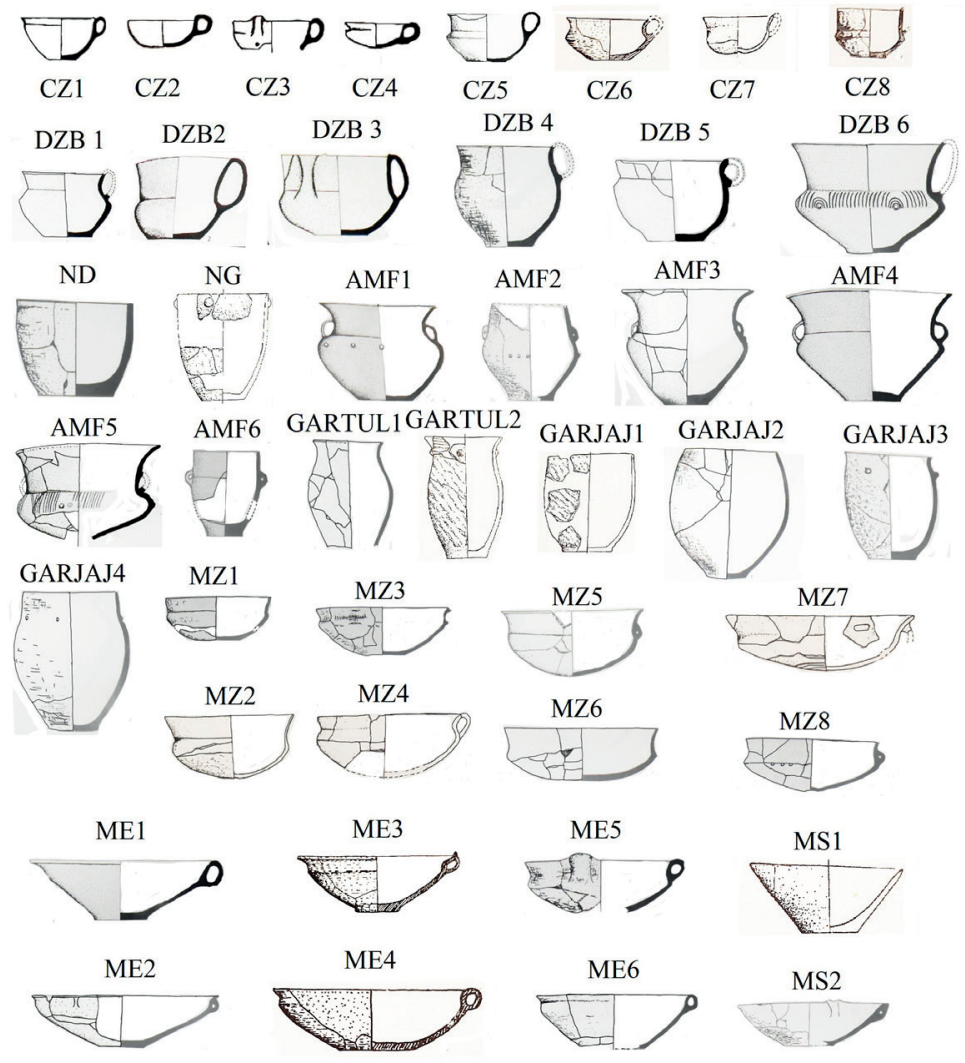

Tabl. I. Typy naczyń uwzględnione w pracy. Furmany: CZ1 - 303 (tabl. CXII, 1); CZ5 - 275 (tabl. XCVII, 6); DZB1 - 86 (tabl. XXI, 1); DZB2 - 311 (tabl. CXVI, 2); DZB3 - 222 (tabl. LXXVIII, 2); DZB - 196 (tabl. LXVII, 5); DZB5 - 48 (tabl. IV, 1); DZB6 - 279 (tabl. C, 3); ND - 173 (tabl. LIX, 5); AMF1 - 310 (tabl. CXVI, 1); AMF2 - 116 (tabl. XXXVI, 3); AMF3 - 328 (tabl. CXXII, 5); AMF4 323 (tabl. CXX, 2); AMF5 - 330 (tabl. CXXIII, 5); AMF6 - 135 (tabl. XLIV, 10); GARTUL1 - 104 (tabl. XXX, 2); GARJAJ2 - 203 (tabl. LXX, 1); GARJAJ3 - 185 (tabl. LXIV, 2); GARJAJ4 - 189 (tabl. LXV, 5); MZ1 - 173 (tabl. LIX, 4); MZ3 - 103 (tabl. XXX, 1); MZ5 - 134 (tabl. XLIII, 12); MZ6 - 78 (tabl. XVIII, 3); MZ8 - 76 (tabl. XVII, 1); ME1 - 278 (tabl. XCIX, 4); ME2 - 138 (tabl. XLV, 6); ME5 - 116 (tabl. XXXVI, 4); ME6 - 104 (tabl. XXX. 3); MS2 - 142 (tabl. XLVI, 4); Pysznica: CZ2 - 750 (tabl. LXXXII, 14); CZ3 - 753 (tabl. LXXXII, 8); CZ4 - 763 (tabl. LXXXIII, 7); CZ7 - 629 (tabl. LXVIII, 7); NG - 547 (tabl. LVII, 10); GARTUL2 - 644 (tabl. LXIX, 11); GARJAJ1 - 478 (tabl. L, 3); MZ2 - 665 (tabl. LXXIII, 3); MZ4 - 2 (tabl. XII, 2); MZ7 - 462 (tabl. XLVII, 7; MS1 - 758 (tabl. LXXXIII, 4); Zbydniów: CZ6 - 213 (tabl. XIX, 8); CZ8 - 92 (tabl. IX, 2); ME3 - 74 (tabl. VII, 4); ME4 61 (tabl. VI, 6); za S. Czopek, 2001; K. Moskwa, 1979; K. Ormian, 1998

Tab. I. Types of vessels included in the work. Furmany: CZ1 - 303 (tab. CXII, 1); CZ5 - 275 (tab. XCVII, 6); DZB1 - 86 (tab. XXI, 1); DZB2 - 311 (tab. CXVI, 2); DZB3 - 222 (tab. LXXVIII, 2); DZB4 - 196 (tab. LXVII, 5); DZB5 - 48 (tab. IV, 1); DZB6 - 279 (tab. C, 3); ND - 173 (tab. LIX, 5); AMF1 - 310 (tab. CXVI, 1); AMF2 - 116 (tab. XXXVI, 3); AMF3 - 328 (tab. CXXII, 5); AMF4 - 323 (tab. CXX, 2); AMF5 - 330 (tab. CXXIII, 5); AMF6 - 135 (tab. XLIV, 10); GARTUL1 - 104 (tab. XXX, 2); GARJAJ2 203 (tab. LXX, 1); GARJAJ3 - 185 (tab. LXIV, 2); GARJAJ4 - 189 (tab. LXV, 5); MZ1 - 173 (tab. LIX, 4); MZ3 - 103 (tab. XXX, 1); MZ5 - 134 (tab. XLIII, 12); MZ6 - 78 (tab. XVIII, 3); MZ8 - 76 (tab. XVII, 1); ME1 - 278 (tab. XCIX, 4); ME2 - 138 (tab. XLV, 6); ME5 - 116 (tab. XXXVI, 4); ME6 - 104 (tab. XXX. 3); MS2 - 142 (tab. XLVI, 4); Pysznica: CZ2 - 750 (tab. LXXXII, 14); CZ3 - 753 (tab. LXXXII, 8); CZ4 763 (tab. LXXXIII, 7); CZ7 - 629 (tab. LXVIII, 7); NG - 547 (tab. LVII, 10); GARTUL2 - 644 (tab. LXIX, 11); GARJAJ1 - 478 (tab. L, 3); MZ2 - 665 (tab. LXXIII, 3); MZ4 - 2 (tab. XII, 2); MZ7 - 462 (tab. XLVII, 7; MS1 - 758 (tab. LXXXIII, 4); Zbydniów: CZ6 - 213 (tab. IX, 8); CZ8 - 92 (tab. IX, 2);

ME3 - 74 (tab. VII, 4); ME4 - 61 (tab. VI, 6); after Czopek 2001; Moskwa 1979; Ormian 1998 
Niezbędnego omówienia wymaga wybór materiałów oraz ich wykorzystanie $\mathrm{w}$ analizach. Jak wspomniano, wykorzystaliśmy dane z trzech największych cmentarzysk z materiałami o „stylistyce nadsańskiej”. Wzięto pod uwagę tylko te groby, w których popielnica zachowała się w całości, co dało 610 inwentarzy, które stanowiły trzon bazy źródłowej. Prowadzono również analizy dla przystawek, przedmiotów metalowych oraz pokryw, jednak ich dodanie skutkowało wytworzeniem się sztucznych grup. Jedynie pokrywy (i to też tylko przy części analiz) nie prowadziły do zafałszowań. $Z$ tej przyczyny autor zdecydował się dołożyć przynajmniej do najogólniejszych analiz pokrywy, pomijając jednak pozostałe przedmioty. Na potrzeby naszych badań wyróżniliśmy 90 typów naczyń (tabl. I-III) oraz 48 wątków zdobniczych (tabl. IV). W procesie kodowania danych posługiwaliśmy się oznaczeniami $0 / 1$, zaznaczając, czy dana cecha wystąpiła (1), czy też nie (0). W przypadku ornamentyki oznaczaliśmy także ilość wątków zdobniczych, jakie pojawiły się na naczyniu oraz miejsce ornamentowania (brzusiec, wylew, część przydenna, szyjka), a także to, czy zdobienie się pojawiło, czy też nie. W przypadku pokryw oprócz oznaczania formy notowano także ich obecność w grobach oraz sposób ich ornamentowania. Dodatkowo w analizach dotyczących całości materiału, aby sprawdzić relację między najważniejszymi fazami rozwoju TKL, oznaczaliśmy chronologię, w ramach której miałby się zamykać dany pochówek. Ogólnie w początkowej fazie badań uwzględniono 201 cech (71 typów popielnic, 75 cech określających ornamentykę popielnicy, 35 typów pokryw, 17 cech określających ich ornamentykę i trzy dla chronologii to, czy naczynie wstępnie przyporządkowano do I, II czy III fazy).

Krótkiego omówienia wymagają kolejne etapy analiz. W początkowej fazie badań wykorzystano całość danych, nie pomijając żadnej z cech, aby sprawdzić, jak bardzo trzy główne fazy rozwoju TKŁ były do siebie zbliżone. W drugim etapie zestawiono ze sobą naczynia o ,stylistyce nadsańskiej” i „ogolnołużyckiej”. W zestawieniu tym pominięto jednak materiały „najstarsze” i „najmłodsze”. Ten etap miał na celu sprawdzenie, czy badane zbiory utworzą wyraźnie odrębne skupiska, czy też powstaną grupy o mieszanym charakterze. W ostatnim, trzecim, etapie pominięto pokrywy oraz te cechy, które pojawiły się w mniej niż w trzech pochówkach, skupiając się tylko na „stylistyce nadsańskiej”. Ten etap jest kluczowy dla podjętego problemu, ponieważ to w nim próbowaliśmy wydzielać mniejsze grupy o omawianej stylistyce.

Na koniec warto podkreślić, że przy każdym etapie staraliśmy się dodatkowo konfrontować wyniki z datami C14. Trzeba jednak zanotować, że niestety dla części wyróżnionych tu grup nie dysponowaliśmy tego typu danymi. Ten problem dotyczy zwłaszcza trzeciego, jak się wydaje najistotniejszego, etapu naszych badań. 


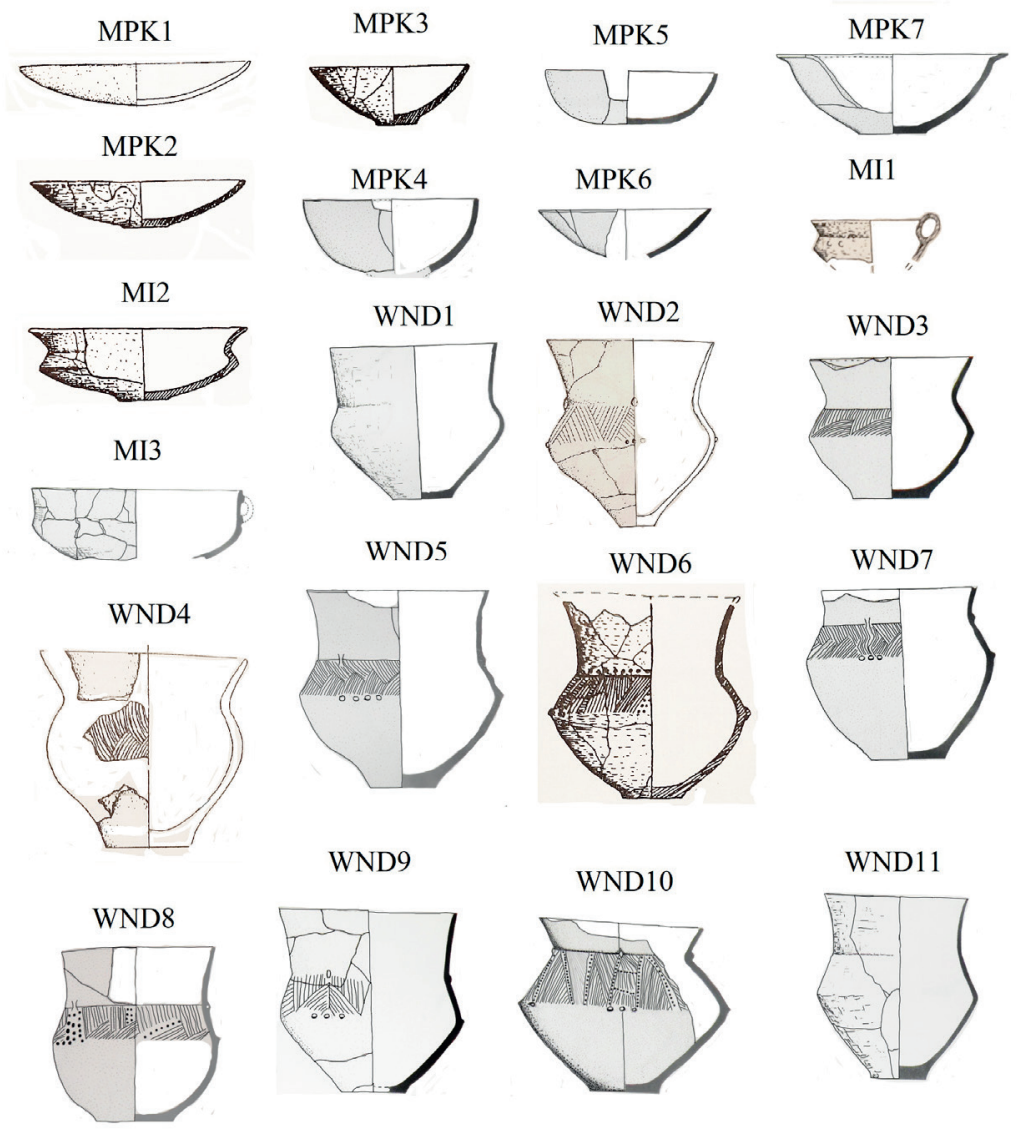

Tabl. II. Typy naczyń uwzględnione w pracy. Furmany: MPK4 - 74 (tabl. XV, 3); MPK5 - 71 (tabl. XIV, 3); MPK6 - 175 (tabl. LX, 3); MPK7 - 289 (tabl. CV, 3); MI3 - 58 (tabl. VIII, 2); WND1 - 62 (tabl. X, 2); WND3 - 78, (tabl. XVIII, 1); WND7 - 72 (tabl. XIV, 7); WND8 - 62 (tabl. XI, 2); WND9 - 172 (tabl. LIX, 2); WND10 - 287 (tabl. CIII, 1); WND11 - 165 (tabl. LVII, 2); WND5 - 52, tabl. V, 4; Pysznica: MPK1 - 554 (tabl. LVIII, 6); WND2 - 90 (tabl. XVIII, 2); WND4 - 178 (tabl. XXVI, 3); Zbydniów: MPK2 - 60 (tabl. VI, 4); MPK3 - 75 (tabl. VII, 7); MI1 - 193 (tabl. XVII, 19); MI2 - 42 (tabl. III, 10); WND6 - 166 (tabl. XVI, 3); za Czopek, 2001; Moskwa, 1979; Ormian, 1998

Tab. II. Types of vessels included in the work. Furmany: MPK4 - 74 (tab. XV, 3); MPK5 - 71 (tab. XIV, 3); MPK6 - 175 (tab. LX, 3); MPK7 - 289 (tab. CV, 3); MI3 - 58 (tab. VIII, 2); WND1 - 62 (tab. X, 2); WND3 - 78, (tab. XVIII, 1); WND7 - 72 (tab. XIV, 7); WND8 - 62 (tab. XI, 2); WND9 - 172 (tab. LIX, 2); WND10 - 287 (tab. CIII, 1); WND11 - 165 (tab. LVII, 2); WND5 - 52, tab. V, 4; Pysznica: MPK1 554 (tab. LVIII, 6); WND2 - 90 (tab. XVIII, 2); WND4 - 178 (tab. XXVI, 3); Zbydniów: MPK2 - 60 (tab. VI, 4); MPK3 - 75 (tab. VII, 7); MI1 - 193 (tab. XVII, 19); MI2 - 42 (tab. III, 10); WND6 - 166 (tab. XVI, 3); from Czopek, 2001; Moskwa, 1979; Ormian, 1998 


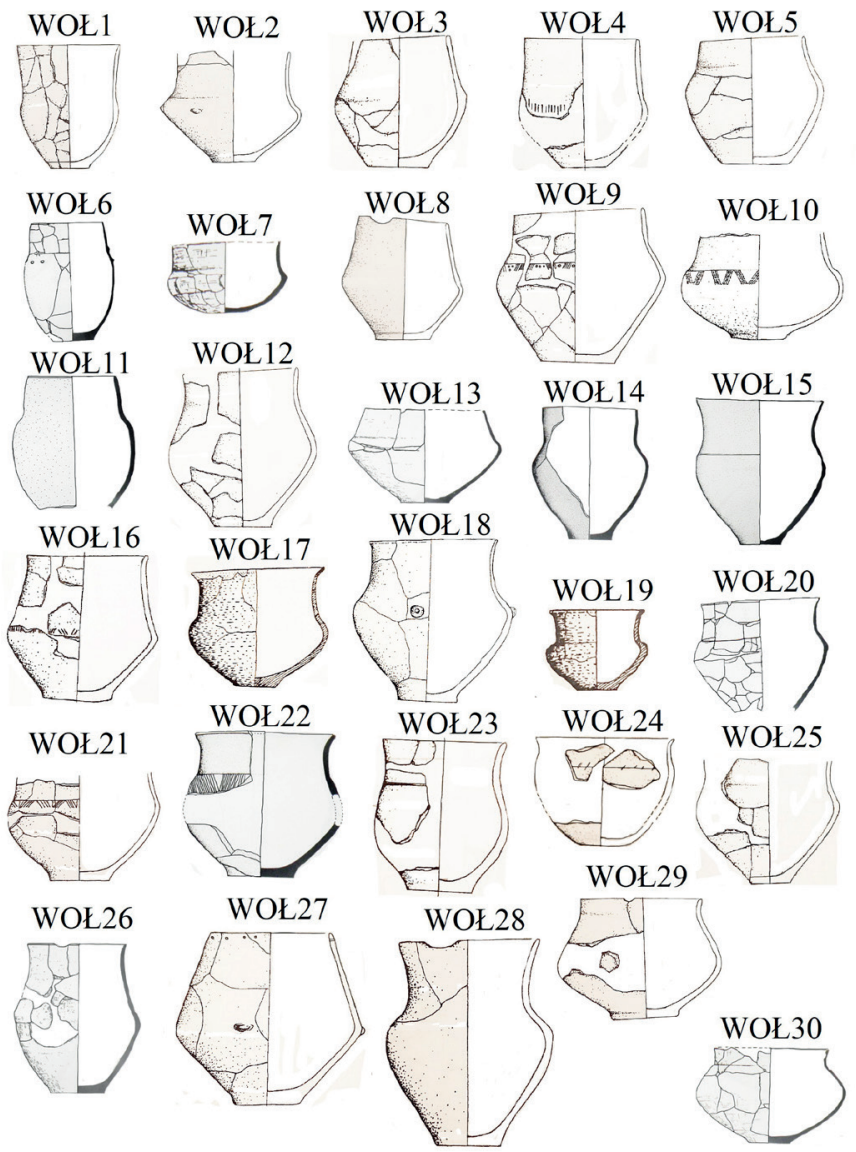

Tabl. III. Typy naczyń uwzględnione w pracy: Furmany: WOŁ6 - 129 (tabl. XLI, 4); WOŁ7 - 201 (tabl. LXIX, 2); WOŁ8 - 743 (tabl. LXXXI, 7); WOŁ11 - 98 (tabl. XXV, 6); WOŁ13 - 105 (tabl. XXX, 4); WOŁ14 - 180 (tabl. LXII, 1); WOŁ15 - 316 (tabl. CXVII, 5); WOŁ20 - 92 (tabl. XXIII, 1); WOŁ22 195 (tabl. LXVII, 1); WOŁ25 - 212 (tabl. XXIX, 5); WOŁ26 - 181 (tabl. LXII, 4); WOŁ30 - 156 (tabl. LIII, 1); Pysznica: WOŁ1 - 280 (tabl. XXXI, 10); WOŁ2 - 643 (tabl. LXIX, 5); WOŁ3 - 111 (tabl. XXII, 3); WOŁ4 - 203 (tabl. XXVII, 5); WOŁ5 - 269 (tabl. XXXII, 9); WOŁ9 - 243 (tabl. XXX, 8); WOŁ10 703 (tabl. LXXVI, 10); WOŁ12 - 100 (tabl. XX, 2); WOŁ16 - 452 (tabl. XLVI, 6); WOŁ18 - 714 (tabl. LXXVIII, 5); WOŁ21 - 728 (tabl. LXVIII, 5); WOŁ23 - 244 (tabl. XXX ,6); WOŁ24 - 575 (tabl. LXII, 11); WOŁ27 - 601 (tabl. LXV, 7); WOŁ28 - 481 (tabl. L, 7); WOŁ29 - 318 (tabl. XXXV, 14); Zbydniów: WOŁ17 - 123 (tabl. XII, 7); WOŁ19 - 63 (tabl. VI ,9); za Czopek 2001; Moskwa, 1979; Ormian, 1998

Tab. III. Types of vessels included in the work: Furmany: WOŁ6 - 129 (tab. XLI, 4); WOŁ7 - 201 (tab. LXIX, 2); WOŁ8 - 743 (tab. LXXXI, 7); WOŁ11 - 98 (tab. XXV, 6); WOŁ13 - 105 (tab. XXX, 4); WOŁ14 - 180 (tab. LXII, 1); WOŁ15 - 316 (tab. CXVII, 5); WOŁ20 - 92 (tab. XXIII, 1); WOŁ22 195 (tab. LXVII, 1); WOŁ25 - 212 (tab. XXIX, 5); WOŁ26 - 181 (tab. LXII, 4); WOŁ30 - 156 (tab. III, 1); Pysznica: WOŁ1 - 280 (tab. XXXI, 10); WOŁ2 - 643 (tab. LXIX, 5); WOŁ3 - 111 (tab. XXII, 3); WOŁ4 - 203 (tab. XXVII, 5); WOŁ5 - 269 (tab. XXXII, 9); WOŁ9 - 243 (tab. XXX, 8); WOŁ10 703 (tab. LXXVI, 10); WOŁ12 - 100 (tab. XX, 2); WOŁ16 - 452 (tab. XLVI, 6); WOŁ18 - 714 (tab. LXXVIII, 5); WOŁ21 - 728 (tab. LXVIII, 5); WOŁ23 - 244 (tab. XXX, 6); WOŁ24 - 575 (tab. LXII, 11); WOŁ27 - 601 (tab. LXV, 7); WOŁ28 - 481 (tab. L, 7); WOŁ29 - 318 (tab. XXXV, 14); Zbydniów: WOŁ17 - 123 (tab. XII, 7); WOŁ19 - 63 (tab. VI, 9); from Czopek, 2001; Moskwa, 1979; Ormian 1998 


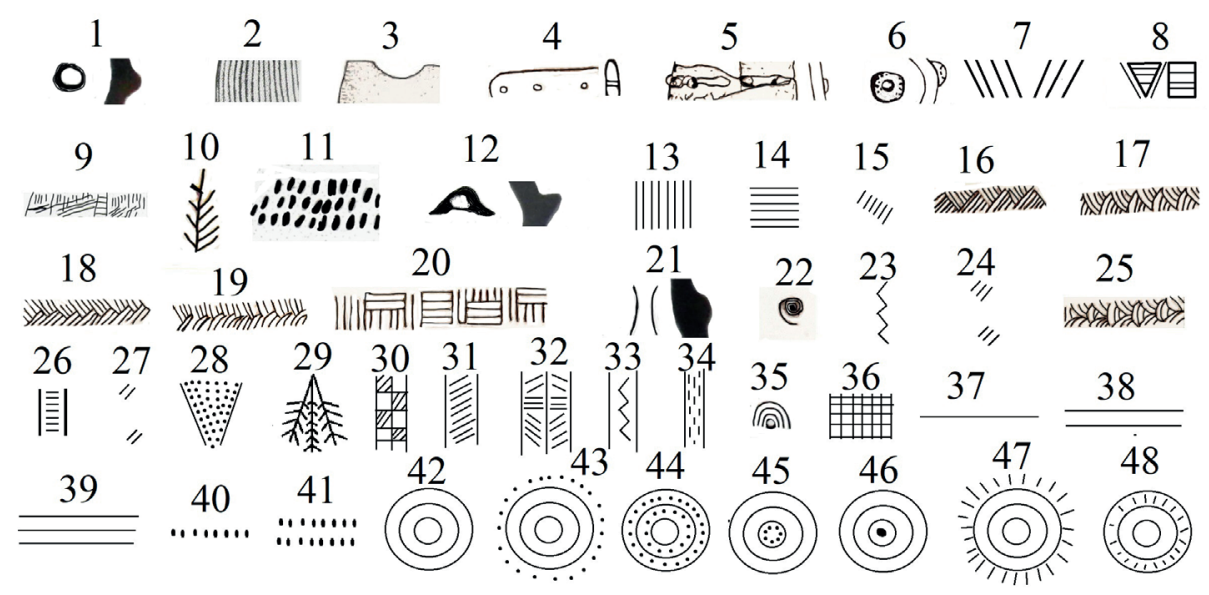

Tabl. IV. Przykłady motywów zdobniczych wykorzystanych w poniższej pracy: 1 - guzki; 2 - chropowacenie; 3 - półokrągłe wcięcie na krawędzi otworu; 4 - otworki pod krawędzią wylewu; 5 - plastyczna listwa; 6 - guzek z dołkiem palcowym; 7 - ukośne linie ryte; 8 - zakreskowane trójkąty i czworokąty; 9 - nieregularne linie ryte; 10 - jodełka; 11 - ornament nakłuć/dołków; 12 - rożkowate guzki; 13 - pionowe linie ryte; 14 - poziome linie ryte; 15 - krótkie ukośne kreseczki; 16 - zakreskowane trójkąty w układzie prostym; 17 - zakreskowane trójkąty w układzie łukowatym; 18 - wilcze zęby w układzie prostym; 19 - wilcze zęby w układzie łukowatym; 20 - zakreskowane czworokąty; 21 - pseudouszka; 22 - spiralna tarczka; 23 - zygzak; 24 - grupy po 3 ukośne linie ryte; 25 - zakreskowane płaszczyzny w układzie nieregularnym; 26 - poziome kreski ujęte w dwie pionowe linie ryte; 27 - grupy dwóch ukośnych linii rytych; 28 - dołki tworzące trójkąty; 29 - trzy gałązki; 30 - szachownica; 31 - ukośne linie ujęte w dwie pionowe linie; 32 - trzy linie ryte między, którymi znajdowały się poziome i ukośne linie; 33 - pionowe linie ryte między nimi zygzak; 34 - pionowe linie ryte, między którymi znajdowały się krótkie kreski; 35 - półokrągłe linie ryte; 36 - kratka; 37 - dookolna linia ryta; 38 - dwie dookolne linie ryte; 39 - trzy dookolne linie ryte; 40 - rząd dookolnych dołków; 41 - dwa rzędy dookolnych dołków; 42 - koncentryczne okręgi; 43 - dołki na zewnątrz koncentrycznych okręgów; 44 - dołki w środku koncentrycznych okręgów; 45 - grupa dołków w środku koncentrycznych okręgów; 46 - jeden dołek w środku koncentrycznych okręgów; 47 - kreski na zewnątrz koncentrycznych okręgów; 48 - kreski między koncentrycznymi okręgami

Tab. IV. Examples of decorative motifs used in the work below: 1 - nodules; 2 - roughness; 3 - semicircular indentation on the edge of the opening; 4 - holes under the rim of the outlet; 5 - plastic strip; 6 - a nodule with a finger fovea; 7 - oblique engraved lines; 8 - hatched triangles and quadrilaterals; 9 - irregular engraved lines; 10 - herringbone; 11 - puncture/holes ornament; 12 - horn-shaped nodules; 13 - vertical engraved lines; 14 - horizontal engraved lines; 15 - short diagonal lines; 16 - hatched triangles in a straight pattern; 17 - hatched triangles in an arcuate pattern; 18 - wolf teeth in a straight configuration; 19 - wolf teeth in an arched configuration; 20 - hatched quadrilaterals; 21 - pseudo-ears; 22 - spiral shield; 23 - zigzag; 24 - groups of 3 diagonal engraved lines; 25 - hatched planes in an irregular pattern; 26 - horizontal lines enclosed in two vertical lines engraved; 27 - groups of two diagonal engraved lines; 28 - holes forming triangles; 29 - three twigs; 30 - chessboard; 31 - diagonal lines framed by two vertical lines; 32 - three engraved lines between which there were horizontal and diagonal lines; 33 - vertical lines carved in a zigzag between them; 34 - vertical engraved lines between which there were short lines; 35 - half-round engraved lines; 36 - check; 37 - circumferential carving line; 38 - two circumferential engraved lines; 39 - three circumferential engraved lines; 40 - row of circumferential holes; 41 - two rows of circular holes; 42 - concentric circles; 43 - holes outside concentric circles; 44 - holes in the center of concentric circles; 45 - group of holes in the center of concentric circles; 46 - one hole in the center of concentric circles; 47 - lines outside concentric circles; 48 - lines between concentric circles 


\section{ANALIZY MATERIAŁÓW}

Graficzny efektem analiz I etapu jest wykres, który przybiera postać zbliżoną do sinusoidy (ryc. 2). Wyniki analizy pokazują, że zdecydowana większość cech układa się w centrum (grupa II - 554 grobów $^{3}$ ), z kolei ramiona (grupy I i III) są słabiej czytelne.

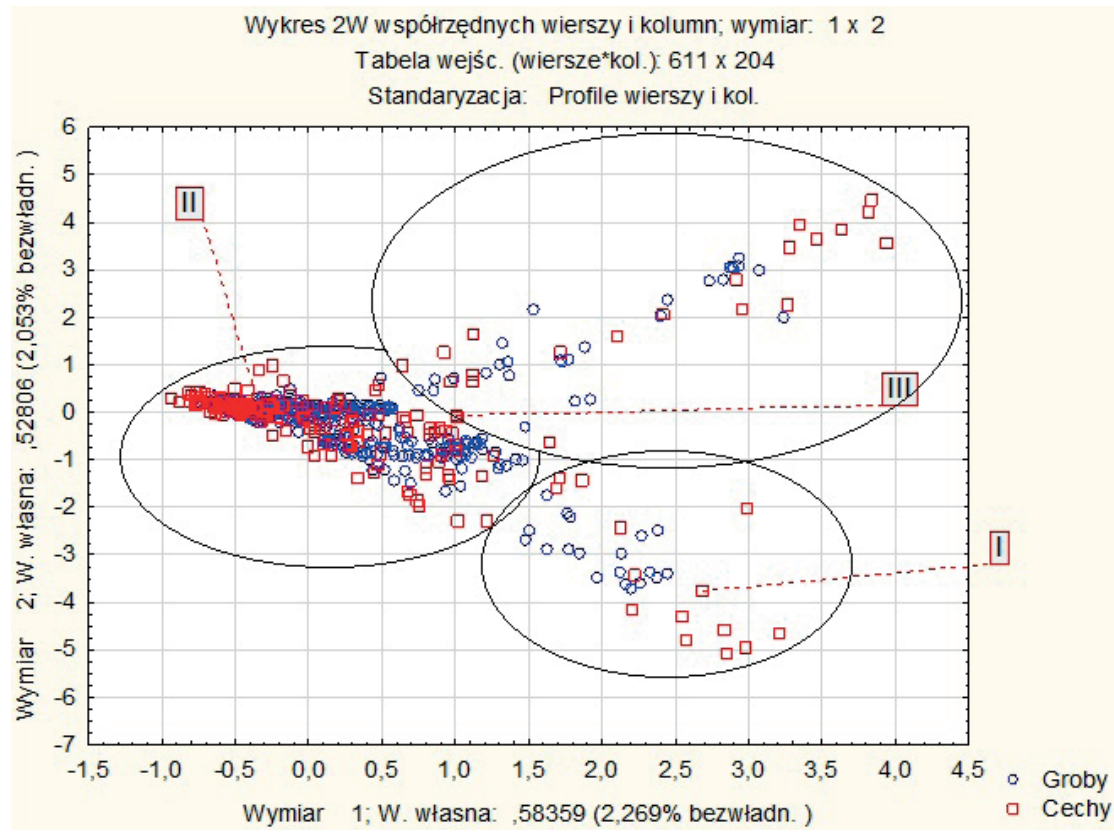

Ryc. 2. Tablica korespondencji prezentująca główne grupy, które powstały po analizie materiałów (popielnic i pokryw) z największych cmentarzysk zawierających stylistykę nadsańską

Fig. 2. Correspondence board presenting the main groups that were created after the analysis of materials (urns and covers) from the largest cemeteries containing the Nadsańska culture style

${ }^{3}$ Furmany - 11, 16, 18, 20, 21, 22, 32, 34, 37, 38, 41, 42, 46, 47, 48, 52, 53, 55, 58, 59, 61, 62, 64 , $65,66,71,72,73,74,75,76,77,78,80,81,82,86,87,89,90,91,92,93,94,96,97,98,99,100,103$, $105,107,108,109,110,116,117,118,121,122,123,124,125,126,128,129,130,131,134,135,138$, $140,142,144,145,147,149,152,153,154,155,156,157,159,160,161,163,164,165,166,167,169$, $170,172,173,174,175,178,180,181,182,183,186,190,192,195,196,197,201,202,204,208,210$, 211, 212, 214A 215, 216, 217, 218, 219, 220, 221, 223, 225, 226, 227, 229, 230, 233, 241, 244, 251A, $252,253,255,256,258,259,260,261,262,268,269,271,273,274,277,278,279,280,282 \mathrm{~A}, 282 \mathrm{~B}$, $283,284,285,286,288,289,297,298,299,306,309,310,311,312,316,317,318,320,322,323,326$, $327,328,329,330,331,333,335,338,339,340,342,343,345,346,347,348$; Pysznica - 2, 8, 12, 23, $28,41,49,50,55,61,81,90,92,95,100,103,105,107,111,112,113,117,119,121,124,127,137,146$, $165,167,178,179,187,188,195,198,203,209,212,220,223,241,243,244,250,251,252,255,263$, $264,266,269,275,282,287,291,294,299,301,319,320,322,325,328,335,340,341,342 \mathrm{~B}, 343,346$, $351,355,357,358,361,409,412,428,432,436,437,442,443,444,447,452,453,454,459,461,462$, $367,375,479,481,482,486,487,489,490,492,493,501,503,506,507,510,518,521,523,524,525$, 
W grupie I (23 groby ${ }^{4}$-ryc. 3) notujemy dwa typy garnków tulipanowatych, traktowanych jako wyznaczniki I fazy rozwoju TKŁ (Czopek, 1996, s. 30-33). Do młodszego odcinka I fazy odnosi się także ME6 (Przybyła, 2003, s. 30, tabl. IX-5). Występuje tu wiele typów czerpaków, szczególnie warto zanotować obecność CZ5 i 6, które można odnosić do fazy I2-3 (Przybyła, 2003, s. 30-31, tabl. II-4 i III-7). Należy jeszcze wspomnieć o WOŁ 1, które odpowiadały typowi 6 wg. typologii Marcina Przybyły i można je łączyć z fazą I2-3 (2003, s. 30, tabl. III-6). Notujemy także naczynia typu DZB2, które można odnosić do I fazy (Przybyła, 2003, s. 30, tabl. II-3). Należy jeszcze

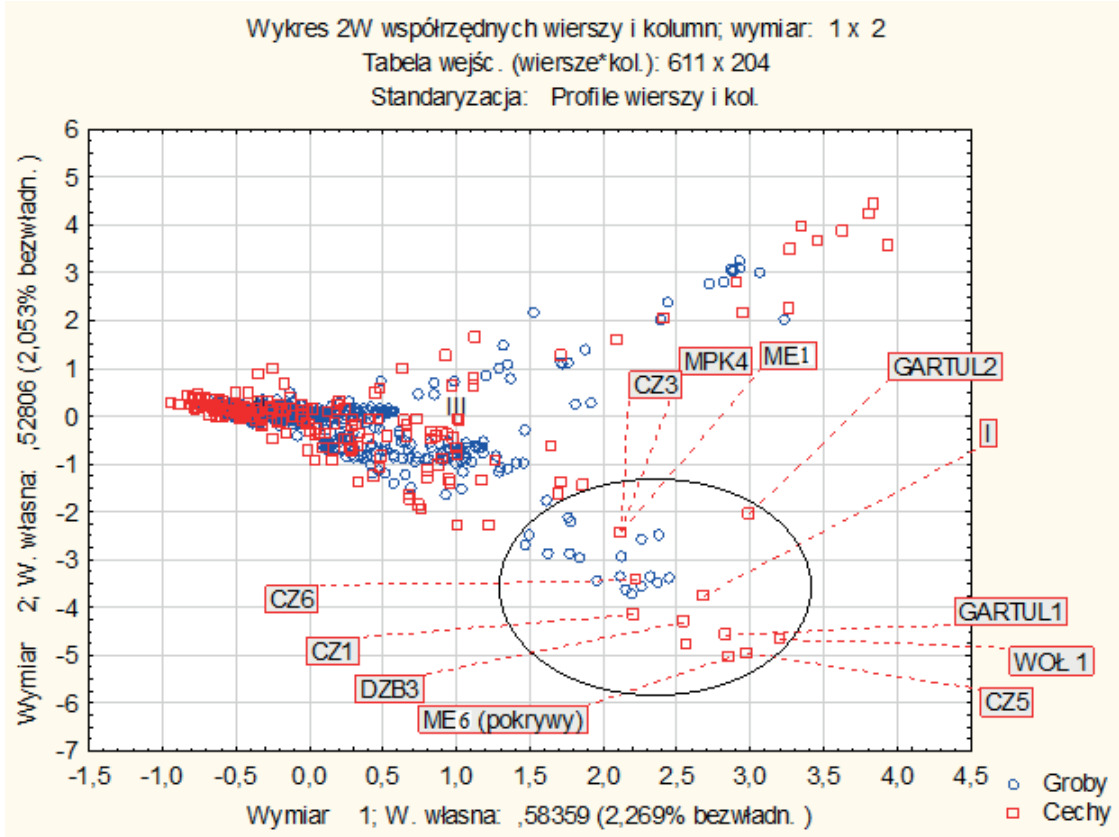

Ryc. 3. Bliższa prezentacja materiałów z grupy I (za ryc. 2)

Fig. 3. Closer presentation of materials from group I (after fig. 2)

$528,530,539,545,546,550,552,553,554,555,556,558,559,561,562,563,565,568,570,572,574$, $575,583,585,588,594,595,596,597,598,600,602,603,604,608,609,610,611,614,621,628,629$, $630,631,633,636,638,643,645,647,648,649,650,653,654,655,657,658,661,665,667,671,672$, $674,675,677,678,679,680,681,682,683,684,695,696,703,704,705,706,707,709,710,712,715$, $717,718,721,723,725,726,727,727,728,732,733,735,737,740,741,744,748,749,750 \mathrm{~A}, 750 \mathrm{~B}$, $756,758,760,763,764,765,767,769,770$; Zbydniów - 3, 6, 8, 10, 11, 12, 21, 23, 26, 28, 33, 35, 36, 37, $38,41,42,43,45,46,47,49,51,52,53,55,56,57,60,61,63,66,67,68,69,74,75,76,77,78,79,80$, $81,83,85,86,90,92,93,94,95,97,98,99,101,103,107,108,109,110,112,114,115,117,120,122$, $123,125,127,128,129,131,132,133,135,136,137,138,141,142,145,146,147,148,149,150,151$, $152,153,154,156,157,159,160,161,165,166,167,168,172,173,177,178,181,182,183,186,187$, 191, 192, 193, 194, 195, 196, 197, 199, 201, 202, 204, 206, 207, 208, 209, 210, 212, 215, 216, 217, 218.

${ }^{4}$ Furmany - 104, 127, 143, 222, 224, 264, 275, 293, 300, 303; Pysznica - 280, 620, 753; Zbydniów $15,22,39,88,91,102,111,184,188,213$. 
wspomnieć o obecności MPK4. Jest to jednak forma niecharakterystyczna, która nie ma walorów chronologicznych (Przybyła, 2003, tabl. IX-37). Z grupą tą nie był związany żaden z ornamentów, brak też pokryw. W zestawieniu nie brano pod uwagę zniszczonych popielnic, stąd wykaz ten nie stanowi kompletnego zestawia pochówków fazy I. Niemniej, co szczególnie interesujące, grupa ta była związana z dziećmi. Na 15 grobów $\mathrm{z}$ analizami antropologicznymi aż 10 to pochówki dzieci. W tej liczbie zawiera się również jeden pochówek podwójny kobiety i dziecka. Ta liczba mogła być nawet większa, ponieważ w 5 grobach, bez oznaczeń antropologa, notujemy niewielkie naczynia, co sugerowałoby pochówki dzieci (Rajpold, 2019, s. 289). Jest to o tyle ciekawe, że na cmentarzyskach, gdzie materiały z II fazy wyznaczają najstarszy horyzont, dostrzega się ich związek z dziećmi oraz kobietami (Trybała-Zawiślak, 2019, s. 93-94). To przeżywanie się starszych tradycji w pochówkach dzieci trwałoby więc nieprzerwanie przynajmniej do początków III fazy rozwoju TKŁ.

Drugi koniec osi - grupa III (26 grobów g $^{5}$ ryc. 4) skupia najmłodsze elementy TKŁ, czyli naczynia jajowate chropowacone na całej powierzchni z guzkami oraz plastycznymi listwami (GJ1, 2, 3) (Przybyła, 2003, s. 41). Dalej występują cechy, które również wskazują na młodszy odcinek III fazy rozwoju, a mianowicie otworki

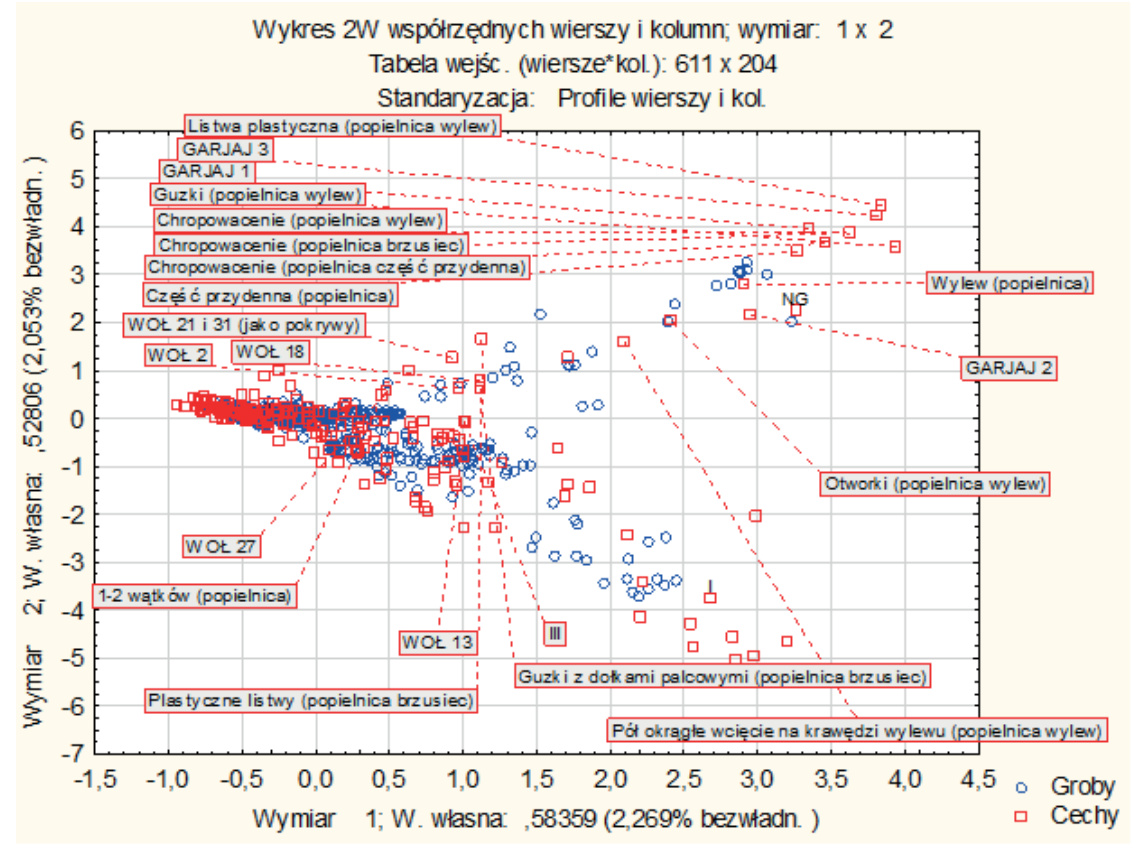

Ryc. 4. Bliższa prezentacja materiałów z grupy III (za ryc. 2)

Fig. 4. Closer presentation of materials from group III (after fig. 2)

${ }^{5}$ Furmany - 14, 43, 45, 54, 162, 198, 199, 263, 266, 325, 336; Pysznica - 116, 318, 478, 547, 601, 644, 660, 693, 697, 702, 714, 722, 729, 736, 743. 
pod krawędzią wylewu i półokrągłe wcięcie (Czopek, 1996, s. 69). Następne są materiały, które można odnosić do starszej części III fazy, jak WOŁ 27 i 29, odpowiadające typom 21 i 22 (Przybyła, 2003, tabl. VI-21 i 22). Notujemy także WOŁ 2, 18 i 20, nawiązujące do typu $17 \mathrm{wg}$. typologii M. Przybyły (2003, tabl. V-17), można je datować na koniec II i początki III fazy TKŁ. Pozostał typ WOŁ 30, któremu najbliżej do typu 32 (Przybyła, 2003, tabl. VIII-32). Naczynie to nie ma jednak walorów chronologicznych. Dalej rejestrujemy materiały złączone w jedną grupę z materiałami z II fazy rozwoju TKŁ. Do omówienia tej grupy przejdziemy w dalszej części. Otrzymany obraz jest odbiciem problemu z rozgraniczeniem materiałów z końcowego etapu fazy II i początków III fazy rozwoju TKŁ. Istnieje też grupa elementów, które można datować na przełom faz II/III. W tym miejscu warto jednak odnotować, że na 22 pochówki z określeniami antropologa notujemy tylko 5 pochówków dzieci oraz trzy pochówki dorosłego i dziecka. Co też ciekawe, grupa ta wiązała się z kobietami, bowiem odnotowano wśród nich aż 7 pochówków żeńskich (dwa podwójne - kobiety i dziecka oraz jeden mężczyzny i kobiety), przy tylko dwóch grobach mężczyzn (tylko jeden pojedynczy). Widać więc, że grupa najmłodszych naczyń jest mocno powiązana z osobami dorosłymi i, co ciekawe, osobnikami płci żeńskiej. Zarysowuje się więc pewien trend, bowiem, jak wspomnieliśmy wcześniej, te materiały, które się przeżywały na danym cmentarzysku, czyli były najstarsze, łączyły się z dziećmi. Teraz widzimy, że materiały najmłodsze mocno łączyły się z dorosłymi. Jest to więc kolejne potwierdzenie szybszego „wprowadzania” nowych naczyń w pochówkach osób dorosłych.

Powyższe dane warto skonfrontować z datowaniem C14, wykonanym dla nekropolii w Pysznicy (Czopek, 2001, s. 168-169; Trybała-Zawiślak, 2019, s. 151-154; tab. 1, ryc. 5).

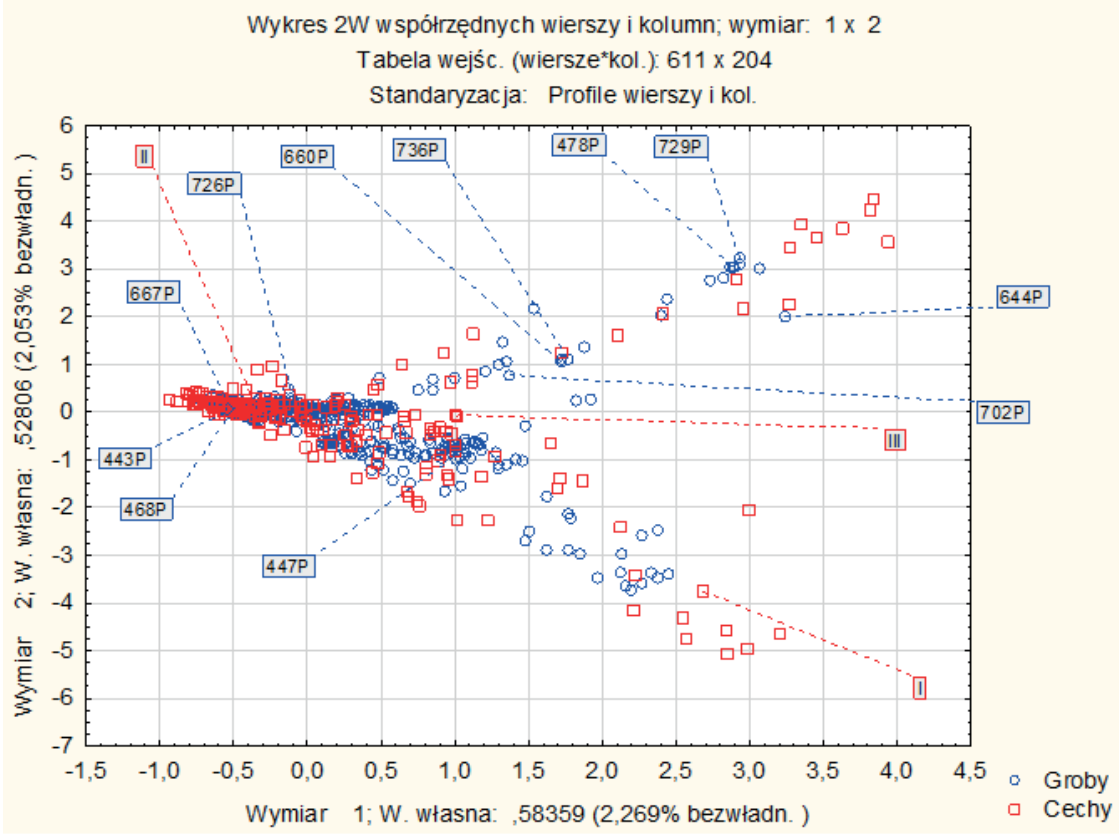

Ryc. 5. Groby zawierające daty C14 (za ryc. 2)

Fig. 5. Graves with the $\mathrm{C} 14$ dates (after fig. 2) 
Co prawda, dysponujemy tylko 14 datami (dla 11 grobów), w dodatku brak wśród nich oznaczeń dla najstarszej fazy. Jest to jednak dobry test skuteczności powyższej analizy. I tak w grupie z materiałami najmłodszymi mamy trzy daty (z grobów 478, 644 i 729). W przypadku najmłodszej z nich z prawdopodobieństwem $68,2 \%$ mamy wskazanie na przedział między 481 a $210 \mathrm{BC}$, z kolei dla najstarszej najbardziej prawdopodobnym (51\%) przedziałem jest okres 548-398 BC. Mielibyśmy więc daty raczej z IV i V wieku p.n.e. Jeśli chodzi o materiały ze starszej części III fazy, to dysponujemy dla nich trzema oznaczeniami wieku bezwzględnego (z grobów 660, 702, 736). Najmłodsze z nich z $68,2 \%$ prawdopodobieństwem wskazuje na okres między 742 a 384 BC, a najstarsza na przedział między 800 a 542. Prawdopodobna jest chronologia przypadająca na okres pomiędzy V a VII/VIII w. p.n.e. W przypadku ostatniej z grup, w której znalazły się materiały II-fazowe oraz wczesne materiały z fazy III, dysponujemy serią pięciu dat (z grobów $443,447,468,667,726)$. Najmłodsza $z$ nich na poziomie ufności $68,2 \%$ prawdopodobieństwa zamyka się w okresie między 731 a 390 BC, natomiast najstarsza w przedziale 806 a 549 BC. Jak widać, przytoczone wyżej daty ponownie wskazały na okres od V do końca VIII w. p.n.e.

W drugim etapie analiz (ryc. 6), który polegał na zestawieniu materiałów o stylistyce „nadsańskiej” i „ogólnołużyckiej”, otrzymaliśmy 3 grupy: A (42 groby6), B (149 groby $\left.{ }^{7}\right)$ i C $\left(363\right.$ groby $\left.^{8}\right)$.

${ }^{6}$ Furmany - 38, 55, 61, 64, 72, 76, 77, 78, 89, 103, 125, 201, 288; Pysznica - 55, 119, 124, 291, 301 , 319, 462, 552, 555, 653, 707, 723, 749; Zbydniów - 43, 46, 55, 98, 99, 103, 107, 109, 110, 112, 128, 148, 187, 194, 208, 218.

${ }^{7}$ Furmany $-11,15,16,18,20,22,32,34,37,41,42,46,47,52,58,59,65,66,73,75,80,81,82$, $87,90,92,94,96,97,99,107,110,117,121,122,129,131,134,138,140,144,145,147,149,152,154$, $155,157,159,161,163,164,169,170,172,174,175,178,182,183,186,190,192,195,202,204,208$, $210,211,212,214 \mathrm{~A}, 216,217,218,220,221,226,227,229,233,241,244,251 \mathrm{~A}, 252,253,255,256$, 260, 261, 262, 268, 271, 273, 278, 279, 280, 282A, 282B, 283, 286, 298, 299, 309, 310, 318, 320, 322, 323, 326, 328, 329, 330, 331, 333, 335, 338, 342, 343, 347; Pysznica - 12, 23, 28, 41, 49, 50, 81, 90, 92 , $95,105,112,113,117,121,127,137,146,165,178,179,187,188,195,198,199,203,220,222,243$, $251,263,275,287,292,294,299,322,325,328,340,341,343,346,351,355,357,358,361,409,412$, 428, 432, 437, 443, 444, 452, 453, 454, 454, 459, 467, 468, 475, 482, 486, 487, 490, 493, 506, 518, 521, $523,524,525,528,530,539,545,546,550,553,554,556,558,559,561,562,563,565,570,572,574$, $583,585,588,594,595,596,598,600,602,604,606,608,609,610,611,614,621,628,629,630,631$, $636,643,645,647,649,650,654,655,657,658,661,665,667,669,670,671,672,674,675,677,679$, $680,683,684,703,704,705,706,709,712,715,717,721,725,726,733,735,740,748,750 \mathrm{~A}, 756,757$, 767, 769; Zbydniów - 8, 11, 21, 26, 28, 33, 35, 36, 37, 38, 41, 42, 45, 47, 49, 51, 53, 56, 57, 61, 66, 67, 75, $76,77,78,81,83,85,86,90,93,94,95,97,108,114,115,117,122,125,127,129,131,132,133,136$, $137,138,142,144,146,147,150,151,152,153,154,156,157,159,160,161,165,166,167,168,172$, 181, 183, 186, 192, 193, 195, 196, 197, 201, 202, 204, 206, 207, 210, 216, 217.

${ }^{8}$ Furmany $-21,48,53,62,71,74,86,91,93,98,105,108,109,116,118,123,124,126,128,130$, $135,142,153,156,160,165,166,167173,180,181,196,197,215,219,223,225,230,258,259,269$, 274, 277, 284, 285, 289, 297, 306, 311, 312, 316, 317, 327, 339, 340, 345, 346, 348; Pysznica - 2, 8, 61, $100,103,107,111,167,209,212,223,241,244,250,252,255,264,266,269,320,335,342 \mathrm{~B}, 436,442$, $447,461,479,481,489,492,501,503,507,510,568,575,597,603,633,638,648,678,681,682,695$, 696, 710, 718, 727, 728, 732, 737, 741, 744, 750B, 758, 760, 763, 764, 765, 770; Zbydniów - 3, 6, 10, $12,23,52,60,63,68,69,74,79,80,92,101,120,123,135,141,145,149,173,177,182,191,199,203$, 209, 212, 215. 


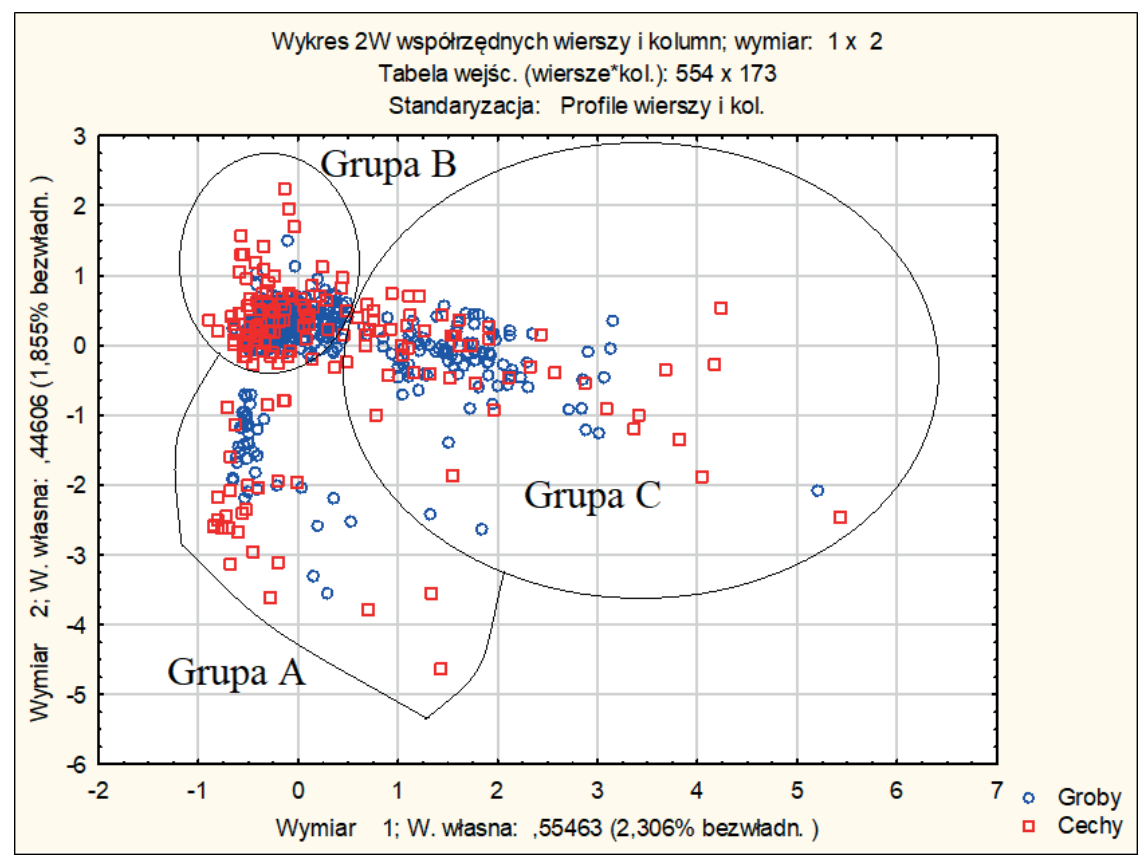

Ryc. 6. Tablica korespondencji prezentująca główne grupy powstałe po analizie materiałów z grupy II

Fig. 6. Correspondence table presenting the main groups created after the analysis of materials from group II

Z grupą A (ryc. 7) związane były głównie pokrywy. Przede wszystkim notujemy misy zbydniowskie typów od 2 do 8 . Co też warte odnotowania, stwierdzono wykorzystanie WOL 20 i 30 jako pokryw. Najsilniejsze związki z tą grupą wykazują pokrywy ornamentowane w strefie dna. Zawierają się tu niemal wszystkie wątki zdobnicze, jakie notowaliśmy w przypadku mis zbydniowskich: koncentryczne okręgi, dołki umieszczane na zewnątrz, wewnątrz oraz między koncentrycznymi okręgami. Prócz tego guzki oraz ornamentyka zaplatanych trójkątów umieszczane na brzuścach pokryw mocno łączyły się z omawianym skupiskiem. Wątki zdobnicze popielnic były już o wiele mniej liczne, notujemy tu wątek dwóch poziomych linii rytych, między którymi umieszczano ukośne linie ryte. $Z$ grupą tą związany był także ornament szachownicy oraz pojedyncze ryte zygzaki, które najczęściej przedzielały inne wątki zdobnicze. Warto zwrócić uwagę na obecność w tej grupie naczyń ze stópkami, które to formy były charakterystyczne dla cmentarzyska w Zbydniowie. Pod względem typów popielnic zespół ten miałby być silniej związany tylko z WOŁ typu 7. W tej grupie stwierdzono także wykorzystanie mis zbydniowskich typów 4, 5 i 6 jako popielnic. Warto zanotować, że typ WOŁ 7 odpowiadałby naczyniom typu 16 względnie $17 \mathrm{wg}$. typologii M. S. Przybyły, który datował je na starszy odcinek II fazy (Przybyła, 2003, s. 40 tabl. V, 16 i 17). Jak wspomniano, grupa ta nie jest związana $\mathrm{z}$ innymi typami 


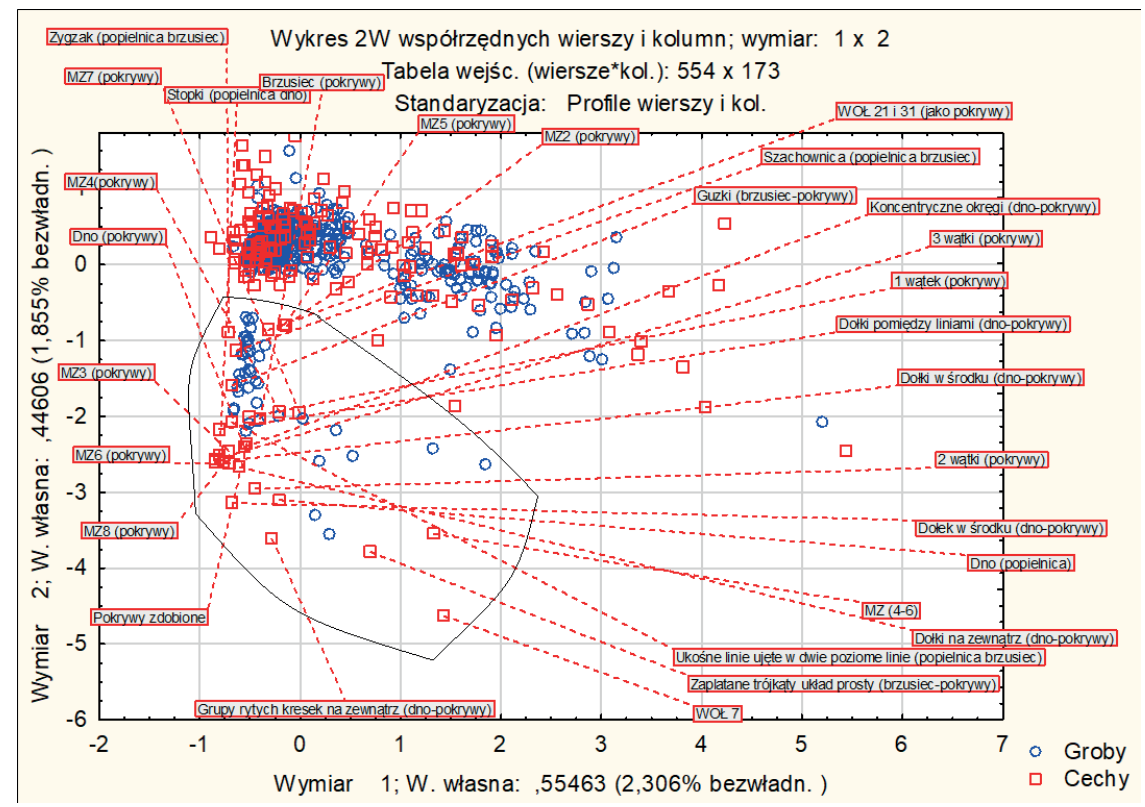

Ryc. 7. Bliższa prezentacja materiałów z grupy A (za ryc. 6)

Fig. 7. Closer presentation of materials from group A (after fig. 6)

popielnic, warto jednak zanotować, że w grobach z tej grupy pojawiają się WND 1, 2, 3, 5, 7, 8, 10, wśród których jednak najpopularniejsze były typy 7 (9 naczyń) i 10 (11 naczyń). Warto zanotować, że cechą wspólną tych najpopularniejszych grup jest krótka szyjka. Odnośnie waz „ogólnołużyckich” musimy zanotować, że pojawiały się tylko w pojedynczych egzemplarzach. Obserwacja ta dotyczy również typu WOŁ 7. Oprócz wspomnianego naczynia notujemy WOŁ 10, 11, 19 (każdy tylko w jednym egzemplarzu). Należy podkreślić, że WOŁ 10 i 11 były najbardziej zbliżone do typów 21 i 23 wg. M. S. Przybyły i można je datować na III fazę TKŁ (Przybyła, 2003, s. 41, tabl. VI-21 i 23). Również typ WOŁ 19 związany był z III fazą rozwoju TKŁ (Przybyła, 2003, s. 41, tabl. VII-25).

Grupa B jest najliczniejsza i najmocniej związana ze „stylistyką nadsańską”. Notujemy w niej wszystkie typy WND oraz wszystkie wątki zdobnicze związane z tym stylem (np. wilcze zęby, zakreskowane trójkąty). Pokrywy pojawiają się tu sporadycznie i zwykle nie są ornamentowane. W przypadku mis zbydniowskich tylko typ MZ5 (10 naczyń) był popularniejszy, ponadto są to w większości naczynia niezdobione. Brak tu silnego związku z innymi typami pokryw, niemniej warto zanotować, że w grobach z tej grupy pojawiały się ME 1 i 2 które można odnosić do II fazy rozwoju TKŁ (Przybyła, 2003, s. 40, tabl. 18). Pojedynczo jako pokrywy pojawiają się także czerpaki typów CZ 1, 3, 4, 5, 6 i 7, a jak wcześniej wspomniano CZ 5 i 6 mocniej łączyły się z fazą IB (M. S. Przybyła, 2003, s. 30-31, tabl. II-4 i III-7). Odnosząc się do waz „ogólnołużyckich”, 
można mówić o silniejszym ich związku z typami WOŁ 4, 8, 17, 18, 21, 22, 27. Liczniejsza była grupa WOŁ 4 (6 naczyń), którą można zaliczyć do typu 15 wg Marcina Przybyły i jako takie można je datować na fazę IIa (2003, s. 40, tabl. IV-15). Kolejną liczniejszą grupę WOŁ 13 (12 naczyń) można datować na początek III fazy (Przybyła, 2003, s. 41, tabl. VII 28). Z kolei WOŁ 21 (10 naczyń) można odnosić do młodszego odcinka II fazy (Przybyła, 2003, s. 41, tabl. V-17). Należy zaznaczyć, że ostatnie z wymienionych (WOE 13 i 21) były też związane z grupą C. Z tym że w tym zespole występowały naczynia ornamentowane, podczas kiedy w $\mathrm{C}$ nie były one zdobione. Na koniec warto wspomnieć o WND 11, który potwierdzono na 28 naczyniach. Były to popielnice zdobione mocno zubożoną stylistyką nadsańską, ograniczającą się do wybranych motywów, jak np. zakreskowane trójkąty czy wilcze zęby. Należy tu mówić o formach zdegenerowanych, postklasycznych, które zdaniem Sylwestra Czopka reprezentują najmłodsze materiały o „stylistyce nadsańskiej”. Trzeba też zanotować, że w przypadku tych naczyń rejestrujemy podobną sytuację jak dla WOŁ 13 i 21 , których forma wydaje się być specyficzna dla grupy $\mathrm{C}$, jednak ze względu na ornamentykę naczynia te zostały przyporządkowane do grupy B.

Ostatnią z grup C (ryc. 8) tworzą wazy „ogólnołużyckie” typów 2, 3, 5, 6, 9, $11,12,13,14,15,17,20,24,25,26,29,30$. Szczególnie popularne były WOŁ 3 (13 naczyń), 13 (12 naczyń), 20 (10 naczyń). Dwa pierwsze odpowiadały typom 27 i 28 wg M. S. Przybyły i można je odnosić do III fazy rozwoju TKŁ (Przybyła, 2003, s. 41, tabl. VII-27 i 28). Trzeci to materiały, które można datować na młodszy

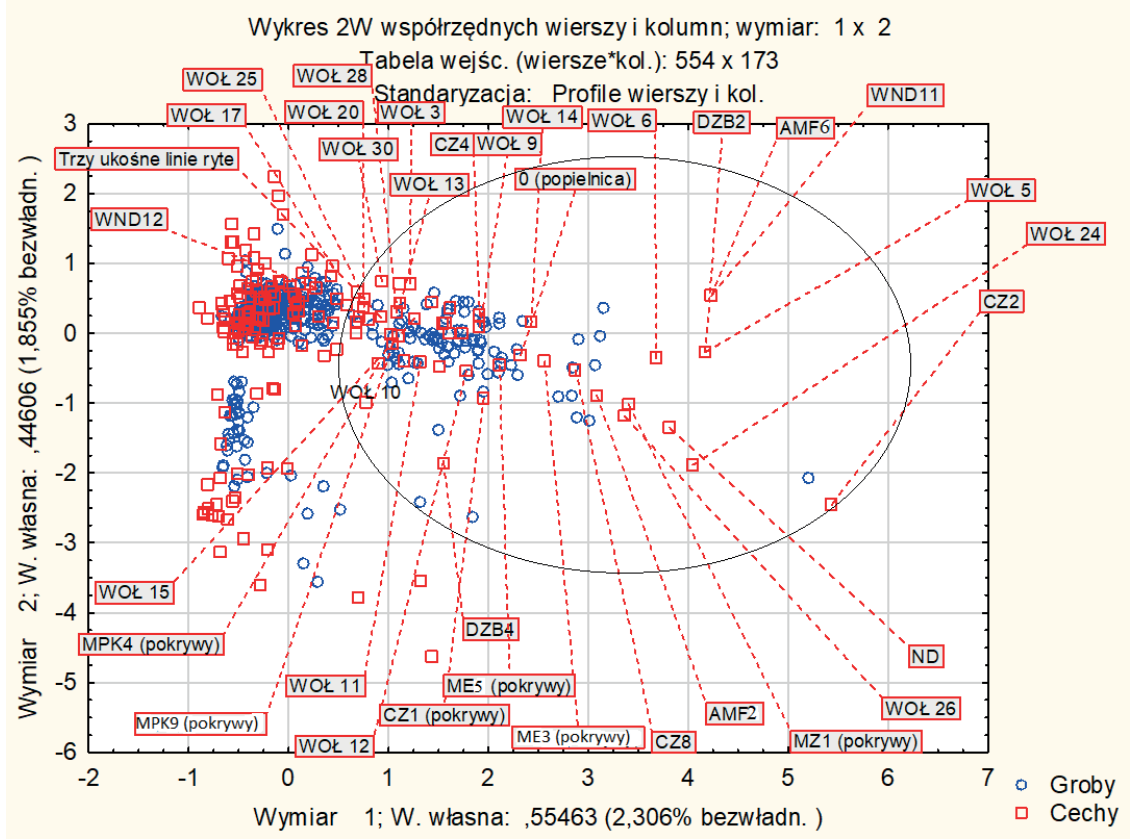

Ryc. 8. Bliższa prezentacja materiałów z grupy C (za ryc. 6)

Fig. 8. Closer presentation of materials from group C (after fig. 6) 
odcinek II fazy TKŁ (Przybyła, 2003, s. 40, tabl. V-17). W przypadku pozostałych mniej licznych typów również mamy materiały z pogranicza końca II i początków III fazy rozwoju TKŁ. Jako pokrywy popularne były misy półkoliste i stożkowate, które pojawiły się we wszystkich typach, jednak najczęściej pod postacią MPK 4, który nie ma jednak walorów chronologicznych (Przybyła, 2003, tabl. VIII- 29, 37, 40, 41 i 42). Innymi formami pokryw pojawiających się w tym zestawie były ME 3 i 5, które można odnosić do typów 18 i 19, co datowałoby je na II oraz początek III fazy rozwoju TKŁ (Przybyła, 2003, s. 40-41, tabl. 18 i 19). Warto zanotować, że w grupie tej mamy naczynia niezdobione lub skromnie zdobione. Jedyny wątek ornamentacyjny powiązany z tym skupiskiem to potrójne ukośne linie ryte umieszczone na brzuścu. Odnośnie „stylistyki nadsańskiej” w zasadzie brak związków z tym skupiskiem. Wyjątek to MZ 1, przy czym należy odnotować, że pojawia się on wyjątkowo rzadko. Liczne były także WND 11. Formy te jednak nie były typowe dla ,stylistyki nadsańskiej”, m.in. z uwagi na brak ornamentyki. W ogóle należy zanotować, że w grobach przyporządkowanych do tego skupiska w pojedynczych przypadkach pojawiały się WND innych typów, jednak były one zwykle niezdobione.

Niestety trudno zweryfikować chronologiczny aspekt przedstawionych powyżej grup na podstawie wyników analizy C14. Dysponujemy tylko 5 datami, z których aż 4 dotyczą grupy B (ryc. 9). Trudno także mówić, aby data z grupy C była młodsza od pozostałych. Niektóre mogłyby być nawet młodsze (z grobów 443 i 726). W kwestii

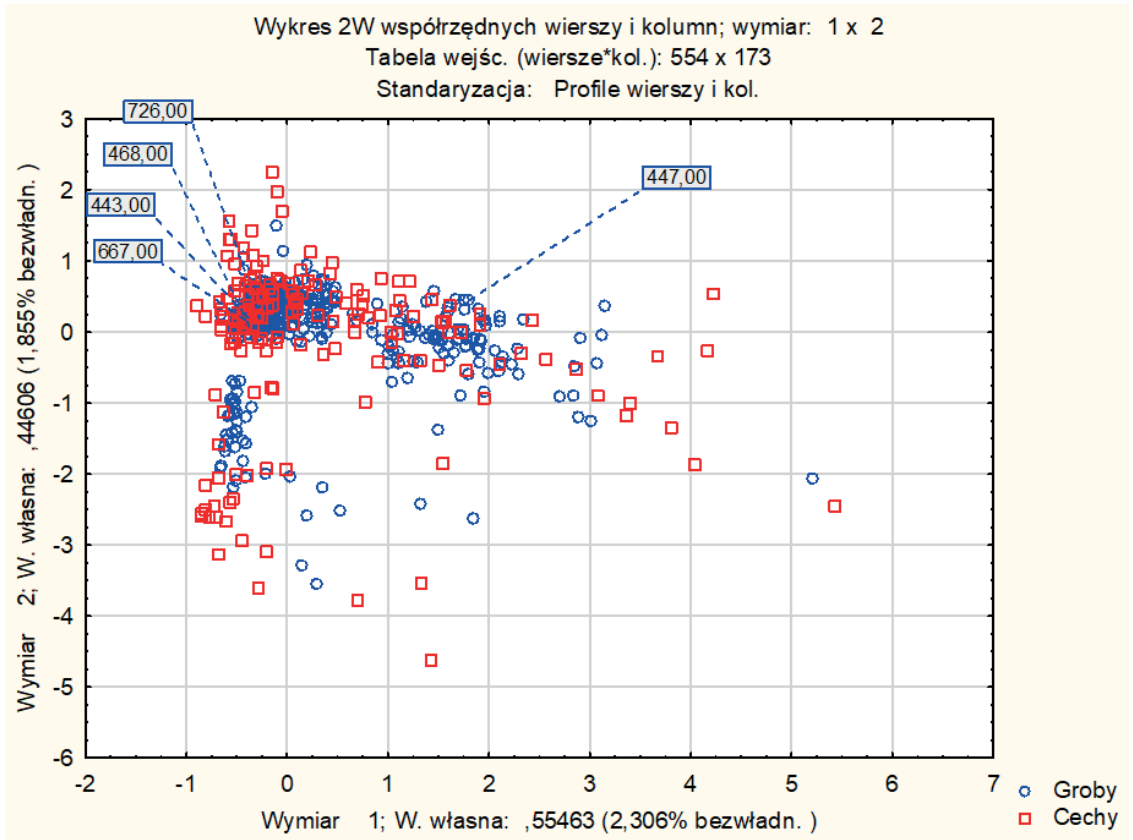

Ryc. 9. Groby zawierające daty C14 (za ryc. 6)

Fig. 9. Graves with the $\mathrm{C} 14$ dates (after fig. 6) 
datowania pod względem stylistyki wydaje się, że materiały z grupy B częściej można odnosić do starszych odcinków II fazy rozwoju TKŁ, podczas kiedy materiały z grupy C to koniec II i początki III fazy. S. Czopek w swojej pracy dotyczącej nekropolii w Pysznicy zastosował bardzo podobny podział (Czopek, 2001, s. 175). W starszej fazie mamy materiały z klasycznymi wazami nadsańskimi oraz naczyniami o stylistyce „ogólnołużyckiej” ze starszej fazy rozwoju TKŁ. W młodszej znalazły się materiały z wazami nadsańskimi zubożonymi oraz naczyniami „ogólnołużyckimi”. Co do grupy A trudno przyjąć, aby faktycznie była ona starsza lub młodsza od grupy B. Wydaje się, że jej odmienność wynikała z dołączenia do zestawienia pokryw, co doprowadziło do sztucznego wydzielenia tej grupy.

Warto jeszcze zanotować, że dalsze analizy materiałów z grup A, B i C nie przyniosły pozytywnych wyników. Niemal zawsze otrzymywaliśmy zwarte skupiska ewentualnie z kilkoma grobami odstającymi, co nie dawało podstaw do wydzielania mniejszych grup.

\section{ANALIZY DOTYCZĄCE „STYLISTYKI NADSAŃSKIEJ”}

Poprzednie dwa etapy potwierdzily dotychczasowe obserwacje na temat „stylistyki nadsańskiej”, m.in. sugestie o jej dłuższym (przynajmniej do przełomu HaC/D) trwaniu (Czopek, 2002, s. 305-306).

Analizy te dostarczają jednak informacji na temat zróżnicowania materiałów o „stylistyce nadsańskiej”. Ostatni (trzeci) etap analiz dotyczy wyłącznie „stylistyki nadsańskiej”. W dalszych badaniach nie uwzględniono innych typów popielnic, pokryw, a także niezdobionych waz nadsańskich oraz rzadkich motywów ornamentacyjnych. Skupimy się jedynie na relacji między formą ornamentyki a typem wazy nadsańskiej. W tym aspekcie całościowe zestawienie danych ze wszystkich uwzględnionych $\mathrm{w}$ analizach nekropolii nie pokazuje większych różnic między badanymi przypadkami. Dopiero zbadanie każdego z cmentarzysk z osobna wskazuje na możliwość wydzielenia pewnych faz stylistycznych.

Niewątpliwie najwięcej danych dostarcza cmentarzysko w Pysznicy. Udało się wydzielić 3 grupy: (14 grobów ${ }^{9}$, ryc. 10), B (67 grobów ${ }^{10}$, ryc. 11) i C (32 groby ${ }^{11}$, ryc. 12).

Najsłabiej wyróżnia się grupa A (zwłaszcza względem B), ponieważ tworzące ją materiały są nieliczne, przez co trudno mówić o jej związku z konkretnym typem popielnicy czy też wątkiem zdobniczym. Trzeba jednak odnotować, że jest to grupa

\footnotetext{
${ }^{9}$ Numery: $117,299,341,412,437,444,546,572,583,604,667,671,749.750 \mathrm{~A}$.

${ }_{10}$ Numery: 23, 28, 55, 81, 90, 92, 95, 124, 127, 137, 146, 178, 187, 188, 195, 198, 199, 220, 222, $251,263,275,282,287,291,292,294,301,319,322,325,328,351,355,361,409,443,453,459,462$, $467,468,482,518,521,523,545,555,558,559,563,570,585,588,609,645,655,661,669,674,679$, $705,706,707,740,756,757$.

${ }^{11}$ Numery: 49, 50, 112, 113, 121, 165, 340, 346, 357, 530, 539, 552, 553, 556, 565, 594, 595, 598, $600,602,614,629,630,636,654,670,683,704,733,735,748$.
} 


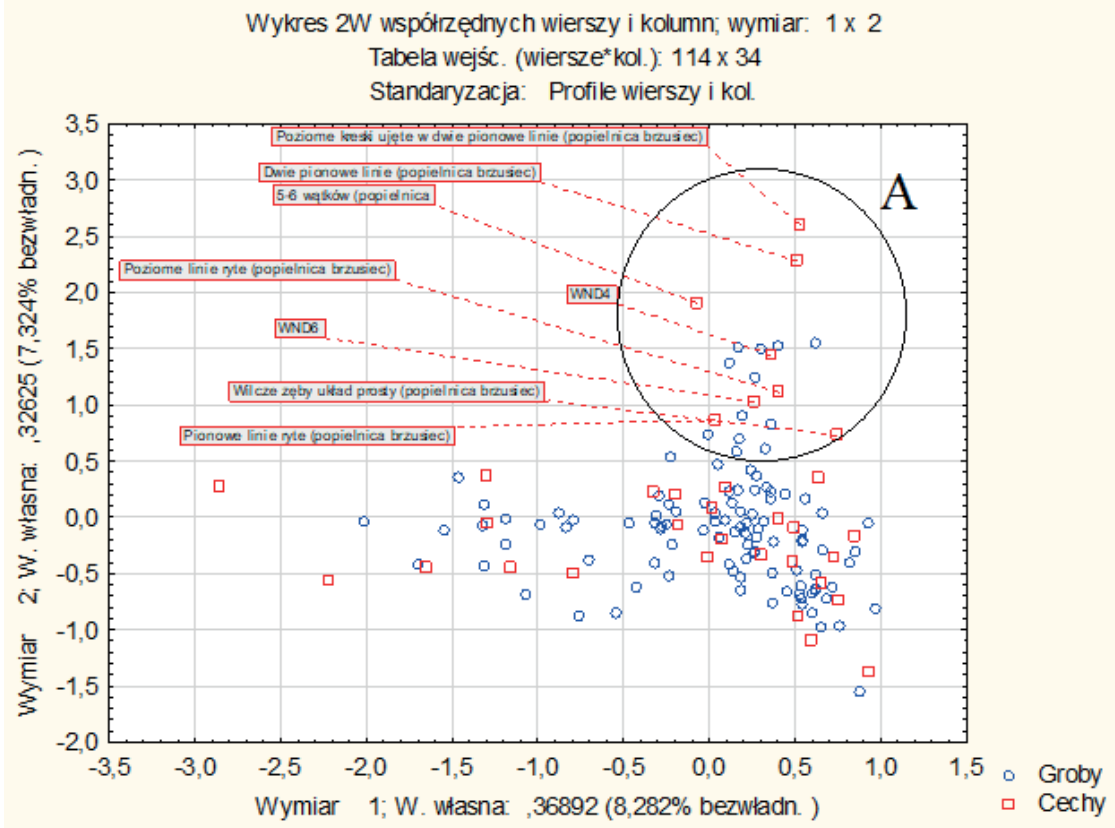

Ryc. 10. Tablica korespondencji dla materiałów o stylistyce nadsańskiej z grupy A dla cmentarzyska w Pysznicy

Fig. 10. Correspondence table for materials with the Nadsańska style from group A for the cemetery in Pysznica

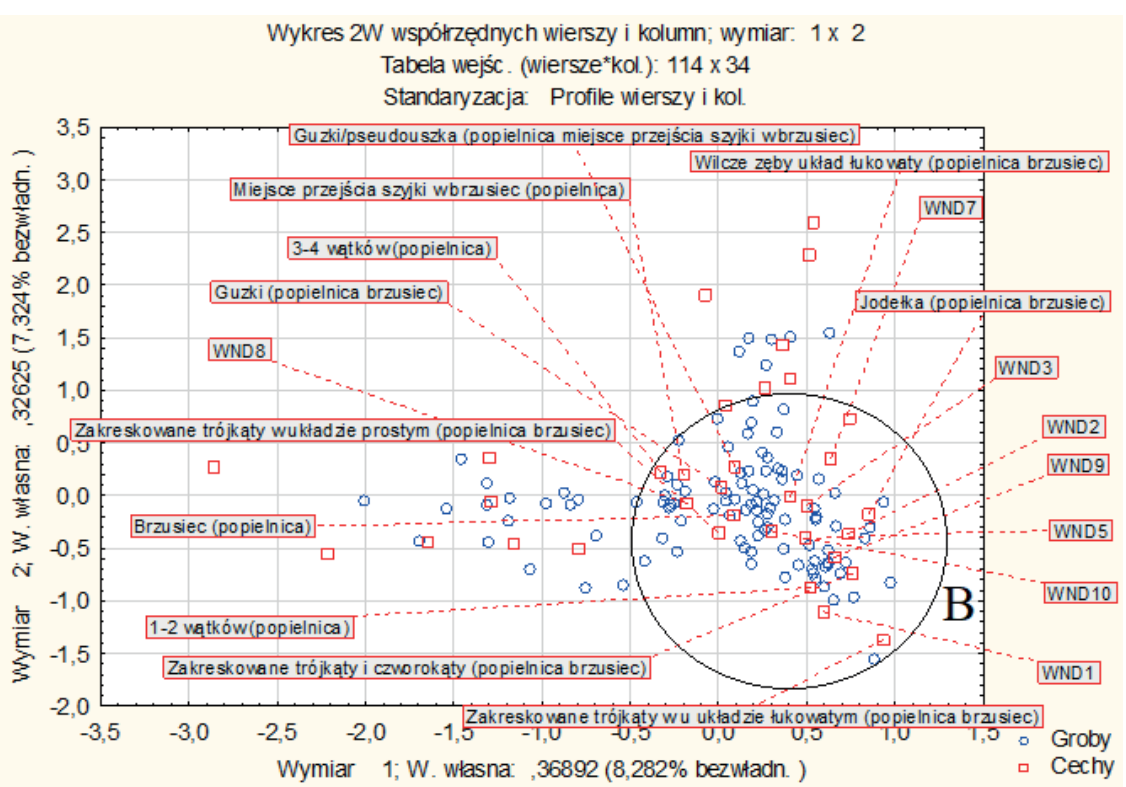

Ryc. 11. Tablica korespondencji dla materiałów o stylistyce nadsańskiej z grupy B dla cmentarzyska w Pysznicy

Fig. 11. Correspondence table for materials with the Nadsańska style from group B for the cemetery in Pysznica 


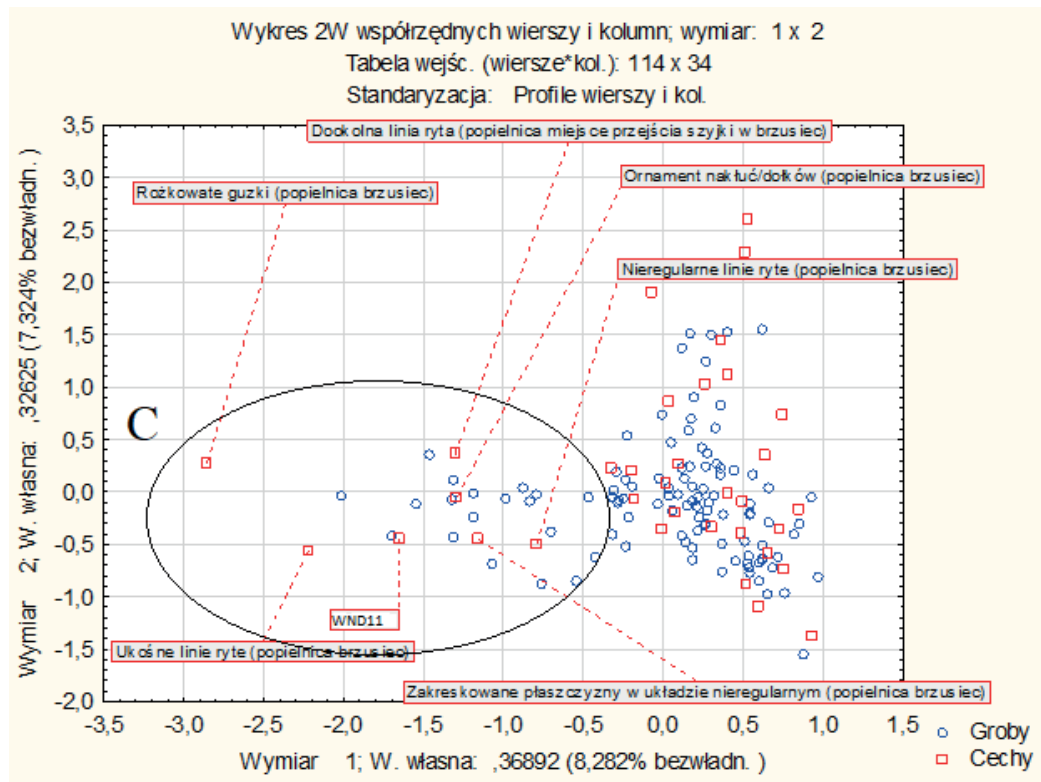

Ryc. 12. Tablica korespondencji dla materiałów o stylistyce nadsańskiej z grupy C dla cmentarzyska w Pysznicy

Fig. 12. Correspondence table for materials with the Nadsańska style from group C for the cemetery in Pysznica

skupiająca naczynia o najbardziej rozbudowanych wątkach ornamentacyjnych, wśród których za najpopularniejsze należy uznać wątek wilczych zębów w układzie prostym i pionowe linie ryte, między którymi znajdują się poziome żłobki.

W porównaniu $\mathrm{z}$ wyżej scharakteryzowaną grupą A, grupa B reprezentowana jest przez znacznie większą serię naczyń i bardzo dobrze wyodrębnia się względem skupienia (grupy) C. Notujemy tu wszystkie typy popielnic oraz większość wątków zdobniczych, jednak zdobienie jest nieco uboższe, a kombinacje złożone z 3-4 wątków. W ramach asortymentu popielnic odnotowano tu wszystkie warianty za wyjątkiem WND 9 i 12. Skupienie to grupuje większość klasycznych elementów dla „stylistyki nadsańskiej”, a mianowicie zakreskowane trójkąty w układzie prostym lub łukowatym, wilcze zęby w układzie łukowatym oraz zakreskowane trójkąty i czworokąty. Z grupą tą związane były także guzki oraz pseudouszka, podkreślenia wymaga jednak to, że również w grupie A pojawiały się one równie często.

Niewątpliwe najciekawsza jest grupa C, w której dominują WND 11 (21 naczyń). Pojedynczo w grobach z tej grupy występują też naczynia innych typów. Ornamentykę z wątków o „stylistyce nadsańskiej” reprezentują zakreskowane płaszczyzny w układzie nieregularnym. Oprócz tego pojawia się dookolna linia ryta w miejscu przejścia szyjki w brzusiec. Podkreślić należy, że cecha ta jest też obecna w pozostałych grupach, jednak w przypadku omawianego obecnie skupienia częściej stano- 
wi ona samodzielny wątek zdobniczy. Odnotowano również rożkowate guzki oraz ukośne linie ryte. Pojawiają się też dołki i nakłucia rozdzielające wątki zdobnicze. Notujemy zubożenie ornamentyki; naczynia zdobiono wątkiem złożonym z 1-2 elementów zdobniczych.

Niestety wydzielonych na podstawie analizy korespondencji grup stylistycznych ceramiki nie jesteśmy w stanie skonfrontować z oznaczeniami wieku bezwzględnego. Do dyspozycji pozostają nam tylko trzy daty (dwie w grupie B i jedną w A), które znacząco nie odstają od siebie, pokazując, że wyjątkowo trudno rozdzielić te grupy. Niestety brak dat odnośnie grupy C, dlatego trudno zweryfikować pozycję chronologiczną tych materiałów względem pozostałych. Niemniej warto zanotować, że mamy tu pewne przesłanki sugerujące, że łączyła ona najmłodsze materiały.

Również w przypadku Furman otrzymaliśmy 3 grupy A (8 grobów ${ }^{12}$; ryc. 13), B (57 grobów $^{13}$; ryc. 14) i C (28 grobów ${ }^{14}$; ryc. 15). I w tym przypadku grupa A słabo

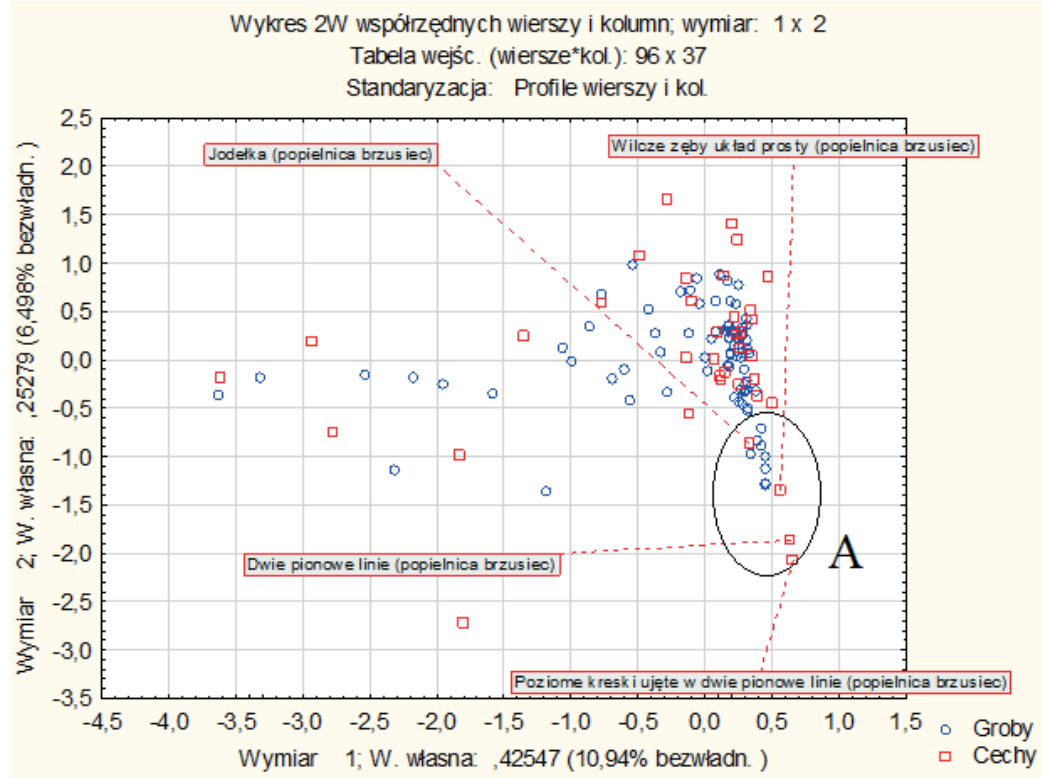

Ryc. 13. Tablica korespondencji dla materiałów o stylistyce nadsańskiej z grupy A dla cmentarzyska w Furmanach

Fig. 13. Correspondence table for materials with the Nadsańska style from group A for the cemetery in Furmany

${ }^{12}$ Numery: 20, 58, 65, 82, 152, 216, 218, 281.

${ }_{13}$ Numery: $11,18,22,37,38,46,52,55,59,61,66,72,73,75,76,80,81,87,89,90,94,96,97,99$, $100,103,121,122,129,131,134,159,161,169,170,174,175,178,183,190,192,202,204,212,233$, $241,244,253,255,256,262,286,288,318,322,214 \mathrm{~A}, 251 \mathrm{~A}$.

${ }_{14}$ Numery: $34,41,64,78,117,138,144,145,147,149,155,163,164,172,186,210,212,226,252$, 260, 268, 271, 273, 278, 280, 309, 320, 329, 333, 342, 343. 


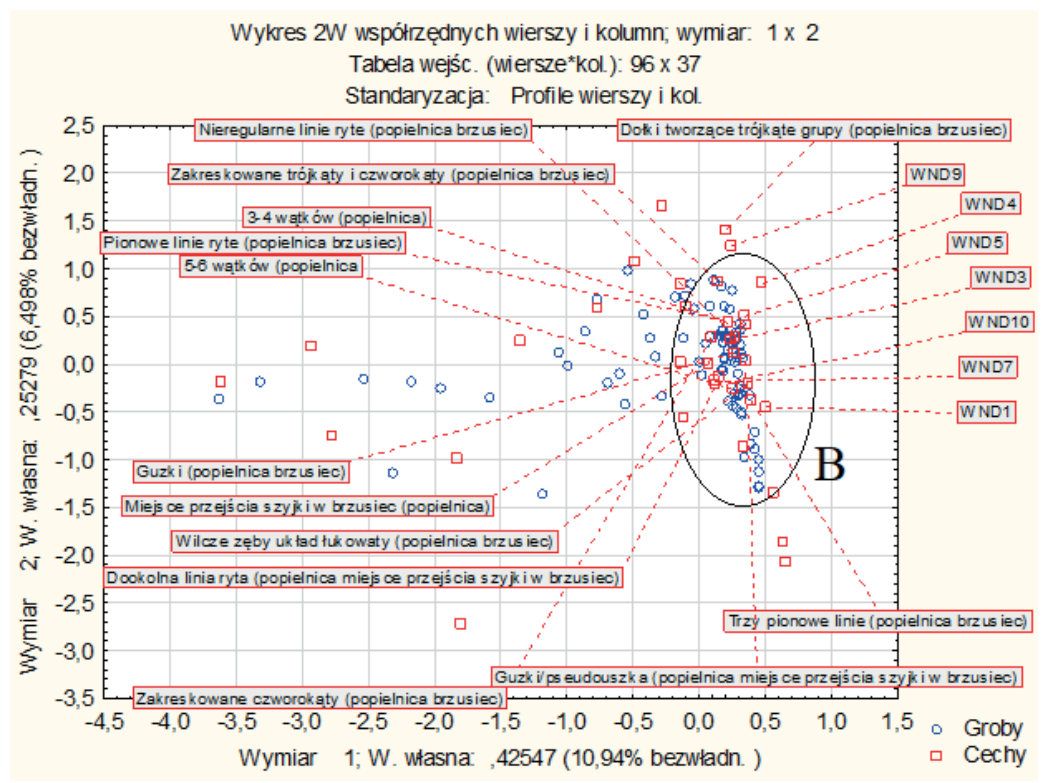

Ryc. 14. Tablica korespondencji dla materiałów o stylistyce nadsańskiej z grupy B dla cmentarzyska w Furmanach

Fig. 14. Correspondence table for materials with the Nadsańska style from group B for the cemetery in Furmany

się wyróżniała względem B. Podobnie jak w przypadku Pysznicy skupisko A łączyło się z ornamentyką wilczych zębów w układzie prostym, a także pionowymi liniami rytymi, między którymi zdarzały się linie poziome. Brak popielnic powiązanych wyłącznie z tą grupą.

Kolejna grupa B, podobnie jak w przypadku Pysznicy, była najliczniejsza i dominująca. Łączyła się z niemal każdym elementem „stylistyki nadsańskiej”. Naczynia były tu bogato ornamentowane, większość wątków skupia 3-4 lub nawet 5-6 styli. Notujemy tu niemal wszystkie typy WND za wyjątkiem 2, 6 i 12. Pewnego podkreślenia wymaga dominacja typów 7 i 10, które były także najliczniejsze na tym cmentarzysku (obok grupy WND 11). W przypadku Pysznicy nie notujemy takiego silnego związku z konkretnymi typami naczyń. Co prawda, najliczniej w grupie B pojawiały się WND 2 i 3, jednak ich przewaga nad innymi typami nie była aż tak silna, jak to miało miejsce w przypadku Furman.

Pozostała jeszcze grupa $\mathrm{C}$ i tu, tak jak w przypadku Pysznicy, rejestrujemy związek z WND 11. Naczynia zdobiono zwykle tylko 1-2 wątkami. Na samym końcu osi pojawiają się również rożkowate guzki. I tu trzeba zanotować, że w przeciwieństwie do Pysznicy grupa ta jest rozciągnięta, a jej część nachodzi jeszcze na grupę B. W grupie granicznej mamy WND 8, pseudouszka, ornamentykę brzuśca, zakreskowane trójkąty w układzie łukowatym. Między tymi dwiema grupami znalazły się uszka w miejscu przejścia szyjki w brzusiec, ornament nakłuć i dołków, a także naczynia WND 2 i 6. 


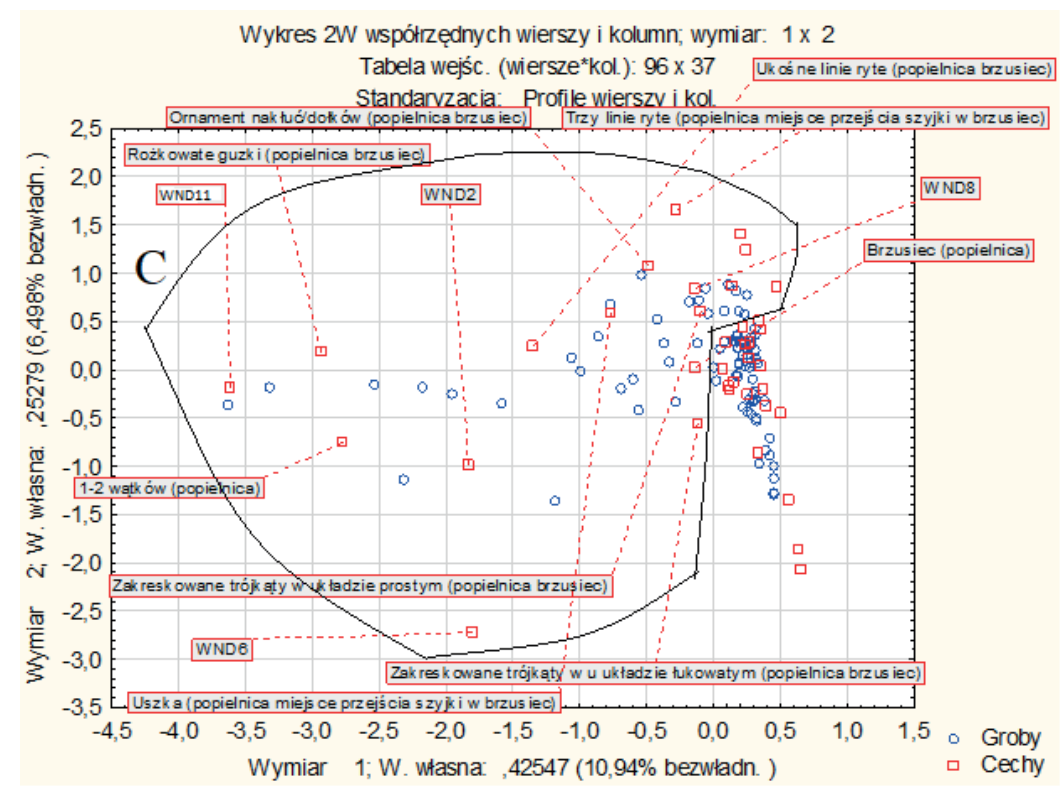

Ryc. 15. Tablica korespondencji dla materiałów o stylistyce nadsańskiej z grupy C dla cmentarzyska w Furmanach

Fig. 15. Correspondence table for materials with the Nadsańska style from group $\mathrm{C}$ for the cemetery in Furmany

Została jeszcze do omówienia nekropola w Zbydniowie (ryc. $16^{15}$ ). W przypadku analizy korespondencji przeprowadzonej dla tego cmentarzyska wykres przybrał postać jednoskupiskową. Niemal wszystkie badane cechy zgrupowały się w jednym miejscu. Należy jednak odnotować, że na badanym stanowisku wystąpiło tylko jedno naczynie typu WND 11. Oznacza to, że cecha najmocniej tworząca grupę C praktycznie nie występuje w tym zestawieniu, a pozostałe charakterystyczne dla tej grupy elementy pojawiają się też w innych badanych przypadkach, stąd obserwowane spłaszczenie. Również dla zgrupowania A nie mamy wyraźnie wyodrębniających się cech (wskaźników). Łączy się ono z ornamentem wilczych zębów, która to cecha jest charakterystyczna również $\mathrm{w}$ grupie B. Co warte podkreślenia, tylko w przypadku Zbydniowa odnotowano naczynia ze stopkami, które wespół $\mathrm{z}$ ornamentem wilczych zębów w układzie prostym mogły stanowić osobną grupę, która znalazłaby się na początku osi tworzącej omawiany układ. Jednak jest to słabo widoczne i grupa ta gorzej, niż w przypadku Furman czy Pysznicy się wyróżnia.

15 Numery: 8, 11, 21, 26, 33, 35, 36, 37, 41, 42, 43, 45, 47, 49, 51, 53, 55, 56, 57, 61, 66, 67, 76, 77, $78,81,83,83,85,86,90,93,94,95,98,103,107,109,110,112,114,122,127,128,131,132,133,136$, $137,138,142,146,147,148,150,152,153,154,157,161,165,166,168,178,181,183,186,187,192$, 193, 194, 195, 196, 197, 201, 202, 204, 206, 207, 208, 210, 216, 217, 218. 


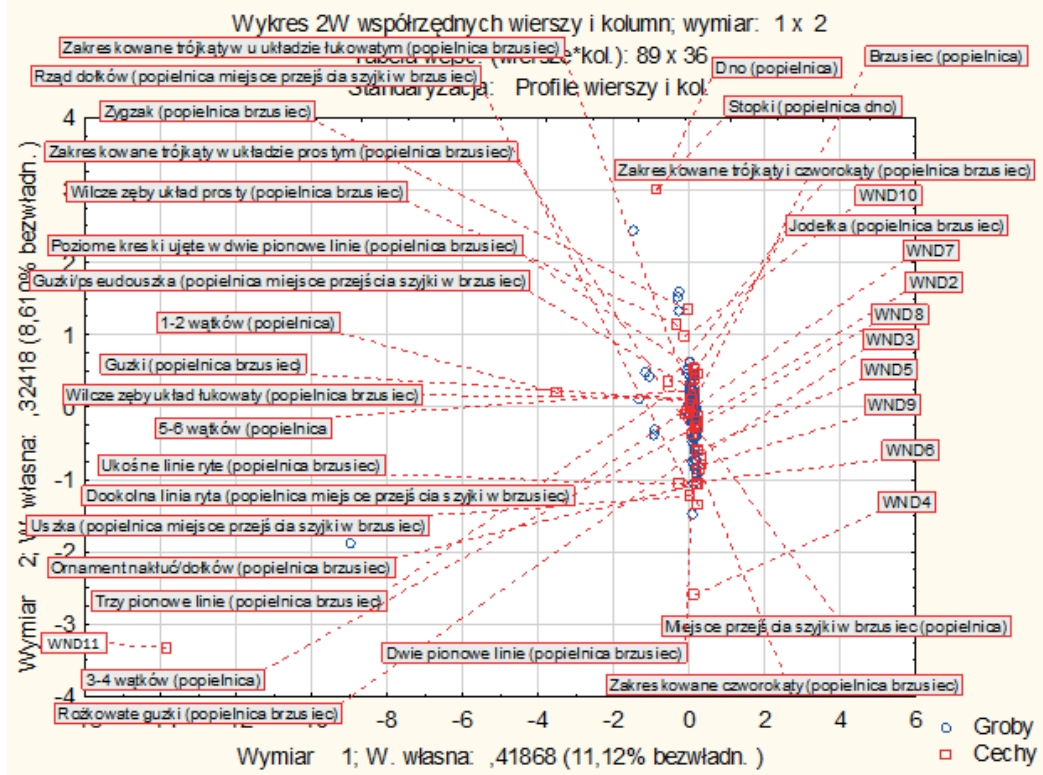

Ryc.16. Tablica korespondencji dla materiałów o stylistyce nadsańskiej dla cmentarzyska w Zbydniowie

Fig. 16. Correspondence table for materials with the Nadsańska style for the cemetery in Zbydniów

Wydaje się więc, że powodem niewyróżnienia grup A i C jest brak większej serii materiałów.

Do tego tematu jeszcze powrócimy w dalszej części pracy, w tym miejscu warto jednak zanotować pewne kwestie. Istnieje przesłanka pozwalająca stwierdzić, że WND 11 wyznaczały najmłodsze materiały o „stylistyce nadsańskiej”. Otóż w poprzednich zestawieniach naczynia te znalazły się w grupie materiałów odnoszonych do okresu na styku II i III fazy rozwoju TKŁ (Czopek, 2001, s. 175-182). Ten moment jest $\mathrm{w}$ analizie dobrze uchwytny, mimo że liczba materiałów uwzględnionych w zestawieniu jest nieliczna. Inaczej sytuacja wygląda w przypadku materiałów najstarszych. Na podstawie wyników naszych analiz wydaje się, że mogły być to naczynia zdobione ornamentyką wilczych zębów w układzie prostym oraz pionowymi liniami rozdzielającymi wątki zdobnicze, a także (tylko w przypadku Zbydniowa) naczynia ze stopkami na dnie. Tu jednak granica jest zamazana. Należy również pamiętać, że te elementy pojawiały się też $\mathrm{w}$ materiałach $\mathrm{z}$ grupy $\mathrm{B}$, co oznacza, że przeżywały się one w głąb tego okresu. Nie mamy też możliwości weryfikacji tych wyników ze względu na niewielką liczbę dat C14. Fakty, jakimi dysponujemy, nie wskazują na różnice w chronologii między grupami A i B. Trzeba wreszcie zanotować, że nawet takie zestawienia ciągle pokazują mocne spłaszczenie materiałów z tej fazy, gdzie zdecydowana większość tworzy jedną zwartą grupę. 


\section{PODSUMOWANIE WYNIKÓW}

Podsumowując, nasze rozważania potwierdziły wcześniejsze opinie o czytelnej granicy między I a II i mniej wyraźnej cezurze między II a III fazą rozwoju TKł (Czopek, 2002, s. 305-306; Trybała-Zawiślak, 2019, s. 86-90). Istotne jest także to, że analizy przeprowadzone dla materiałów z II i początków III fazy potwierdziły również obserwacje Sylwestra Czopka dla cmentarzyska w Pysznicy (Czopek, 2001, s. 175-182), który wydzielił dla tej nekropoli dwie grupy materiałów. Pierwszą z klasycznymi naczyniami o „stylistyce nadsańskiej” oraz tzw. wazami „ogólnołużyckimi”, które należy odnosić do II fazy rozwoju TKŁ. A także druga z materiałami o „stylistyce nadsańskiej” zubożonej i wazach „ogólnołużyckich” odnoszących się do początków III fazy rozwoju TKŁ. Potwierdza to sugestie o wydłużeniu trwania II fazy rozwoju TKŁ nawet do początków HaD. W takim ujęciu materiały określane jako grupa C wyznaczałyby młodszy odcinek fazy II.

Najciekawsze okazały się analizy poświęcone wyłącznie „stylistyce nadsańskiej”. Indywidualne podejście do każdego z uwzględnionych cmentarzysk wskazało kilka powtarzających się elementów, które być może należy interpretować jako swoiste trendy. Być może wskazują one, że zmiany na cmentarzyskach nie zachodziły w sposób synchroniczny. Można zauważyć, że w takim ujęciu forma popielnicy (za wyjątkiem WND 11) nie miała znaczenia chronologicznego, ważniejszy był rodzaj ornamentu. Niemniej, co się wydaje istotne, pewne formy WND były silniej powiązane z konkretnymi cmentarzyskami. Niestety to właśnie owe relacje zaburzyły obraz analiz i doprowadziły do sztucznego złączenia materiałów. Dla Pysznicy oraz Furman rytm przemian był zbliżony, natomiast $\mathrm{w}$ przypadku Zbydniowa notujemy materiały niemal wyłącznie $\mathrm{z}$ grupy $\mathrm{B}$, co sugeruje bardzo wąski przedział czasu, w jakim rozwijałoby się cmentarzysko w Zbydniowe. Powyższe ustalenia pokrywają się z dotychczasowym stanem wiedzy. Wiadomo bowiem, że cmentarzysko w Furmanach reprezentowało najstarsze materiały i rozwijało się do początków III fazy rozwoju TKŁ (Czopek, 2006, s. 106-107). Zbydniów miał się rozwijać od schyłku I fazy przez całą II, brak jednak materiałów III (Czopek, 2006, s. 107). Najmłodsza miała być nekropola w Pysznicy, niemniej i tu pojawiały się materiały z I fazy (Czopek, 2001, s. 183-184). W takim ujęciu otrzymany obraz ze zwartym skupiskiem w Zbydniowie oraz wyróżniającymi się grupami w Pysznicy i Furmanach staje się dla nas czytelny.

Podsumowując, można wysunąć następujące wnioski oraz dalsze postulaty badawcze:

- Analizy z wykorzystaniem analizy korespondencji potwierdziły dotychczasowe ustalenia oraz wnioski, wskazując na słuszność postulatów o wydłużeniu czasu trwania II fazy rozwoju TKL.

- Badania te pokazały, że przy całościowych analizach możemy otrzymać ,jedynie" generalne trendy, czyli podział na tradycyjnie rozumiane fazy I, II i III. Tylko rozdzielenie materiałów na konkretne cmentarzyska oraz skupienie się wyłącznie na jednej fazie rozwoju daje podstawy do szerszych analiz, co z kolei pokazuje, że rytm przemian na różnych cmentarzyskach mógł przebiegać nieco 
inaczej (jakiś element mógł się pojawić wcześniej lub konkretna forma popielnicy była przewodnia).

- Mimo że udało się wskazać materiały, które prawdopodobnie reprezentowały najstarsze i najmłodsze etapy ,stylistyki nadsańskiej”, brak dat C14 uniemożliwia potwierdzenie tych wniosków. Wskazane byłoby wykonanie kolejnych dat C14 dla grobów, które mogły reprezentować najmłodsze i najstarsze materiały, w celu weryfikacji wspomnianych wyników.

- Mimo możliwości wydzielenia pewnych stylów, najprawdopodobniej związanych z młodszym oraz starszym okresem rozwoju ,stylistyki nadsańskiej”, zdecydowana większość materiałów tworzy zwartą grupę. Co niestety pokazuje, że wciąż problematyki II fazy rozwoju TKŁ nie jesteśmy w stanie do końca wyjaśnić.

\section{BIBLIOGRAFIA}

Adamik-Proksa, J.

2019 Ekumena Ludności kultury trzcinieckiej w Polsce poludniowo-wschodniej studium osadniczo-kulturowe (Collectio Archeologica Ressoviensis, t. 40). Rzeszów: Wydawnictwo Uniwersytetu Rzeszowskiego.

Blajer, W., Czopek, S., Kostek, A.

1991 Początek grupy tarnobrzeskiej nad środkowym Sanem. W: M. Gedl (red.), Die Anfänge der Urnenfelderkulturen In Europa (s. 265-293) (Archeologia Interregionalis, t. 13). War-

Czopek, $\mathrm{S}$. szawa: Wydawnictwo Uniwersytetu Warszawskiego

1989 Z badań nad schyłkową fazą grupy tarnobrzeskiej, W: A. Barłowska, E. Szałapata (red.), Grupa tarnobrzeska kultury (s. 241-261). Rzeszów: Muzeum Okręgowe w Rzeszowie.

1996 Grupa tarnobrzeska nad środkowym Sanem i dolnym Wistokiem. Rzeszów: Muzeum Okręgowe w Rzeszowie.

2001 Pysznica, pow. Stalowa Wola, stanowisko 1 - cmentarzysko ciatopalne z przetomu epok brązu i żelaza. Rzeszów: Wydawnictwo Uniwersytetu Rzeszowskiego.

2002 Uwagi o chronologii cmentarzyska w Pysznicy pow. Stalowa Wola w świetle datowań radiowęglowych. W: M. Gedl (red.), Wielkie cmentarzyska z epoki brązu i wczesnej epoki żelaza (s. 291-311). Warszawa: Wydawnictwo Naukowe PWN.

2006 Czas użytkowania cmentarzysk tarnobrzeskiej kultury łużyckiej - możliwości interpretacyjne i uwagi dyskusyjne. Analecta Archaeologica Ressoviensia, 1, 101-132.

2009 Aktualne problemy w badaniach tarnobrzeskiej kultury łużyckiej. W: S. Czopek, K. Trybała-Zawiślak (red.), Tarnobrzeska kultura tużycka - źródła i interpretacje (s. 15-32). Rzeszów: Mitel.

Czopek, S., Trybała-Zawiślak, K.

2015 Early Iron Age in south-eastern Poland. W: M. Wefers, S. Karwowski, J. Fries-Knoblach, P. Trebsche, P. C. Ramsl (red.), Waffen - Gewalt-Krieg (s. 285-301). Wydawnictwo Beier \& Beran, Archäologische Fachliteratur.

Dąbrowski, J.

1980 Przydatność ceramiki łużyckiej dla podziałów kulturowych. W: M. Gedl (red.), Zróżnicowanie wewnętrzne kultury tużckiej (s. 35-55). Kraków: Uniwersytet Jagielloński. 
Gawlik, A., Przybyła M. S.

2005 Początki wczesnej epoki żelaza w Kotlinie Sandomierskiej. W: M. Kuraś (red.), Archeologia Kotliny Sandomierskiej. Rocznik Muzeum Regionalnego w Stalowej Woli, t. 4, (s. 313-352). Stalowa Wola: Muzeum Regionalne.

Gediga, B.

1989 Podstawy wyróżnienia grupy tarnobrzeskiej. W: A. Bartołowska, E. Szałapata (red.), Gru-

Gedl, M. pa tarnobrzeska kultury lużyckiej (s. 15-26). Rzeszów: Muzeum Okręgowe w Rzeszowie.

1962 Uwagi o kulturze łużyckiej w dorzeczu Sanu, Wieprza i górnego Bugu. Sprawozdania Archeologiczne, t. 15 (s. 365-386). Rzeszów: Muzeum Okręgowe w Rzeszowie.

1970 Ze studiów nad genezą i wczesną fazą grupy tarnobrzeskiej. Archeologia Polski, t. 15 (s. 365-386). Wrocław: Zakład Narodowy im. Ossolińskich.

1994 Cmentarzysko z epoki brąu w Bachórzu-Chodorówce. Kraków: Uniwersytet Jagielloński Moskwa, K.

1976 Kultura łużycka w poludniowo-wschodniej Polsce. Rzeszów: Muzeum Okręgowe w Rzeszowie.

1979 Cmentarzysko ciałopalne kultury łużyckiej w Zbydniowie, gm. Zaleszany, woj. Tarnobrzeg. Materiaty i Sprawozdania Rzeszowskiego Ośrodka Archeologicznego za lata 19731975 (s. 3-57). Rzeszów: Muzeum Okręgowe w Rzeszowie.

1982 Tendencje rozwoju grupy tarnobrzeskiej kultury łużyckiej. W: M. Gedl (red.), Poludniowa strefa kultury tu̇̇yckiej i powiazania tej kultury z Poludniem (s. 301-315). Kraków: Uniwersytet Jagielloński.

Mrówka, $Ł$.

2011 Development of pottery style on the Bronze and Early Iron Age cemetery at Kietrz, Głubczyce district, in the light of statistical analyses. Recherches Archéologiques, t. 3, (s. 67100). Kraków: Uniwersytet Jagielloński.

Ormian, K.

1998 Cmentarzysko z epoki brąu i wczesnej epoki żelaza w Furmanach stan. 1, woj. Tarnobrzeg [maszynopis pracy magisterskiej UJ]. Kraków.

2008 Stylistyka nadsańska ceramiki tarnobrzeskiej kultury tużyckiej [maszynopis pracy doktorskiej w UR].

Przybyła, M. S.

2003 Uwagi o chronologii ceramiki grupy tarnobrzeskiej. Materiaty i Sprawozdania Rzeszowskiego Ośrodka Archeologicznego, t. 24 (s. 27-54). Rzeszów: Muzeum Okręgowe w Rzeszowie.

Stanisz, A.

2007 Przystępny kurs statystyki z zastosowaniem STATISTICA PL na przykladach z medycyny, t. 3: Analizy wielowymiarowe. Kraków: StatSoft Polska.

Szarek-Waszkowska, E.

1973 Cmentarzysko kultury łużyckiej w Obojnie, przysiółek Zaosie. Materiały i Sprawozdania Rzeszowskiego Ośrodka Archeologicznego za lata 1970-1972 (s. 73-88). Rzeszów: Muzeum Okręgowe w Rzeszowie.

Trybała-Zawiślak, K.

2012 Kłyżów stan. 2 i Mokrzyszów stan. 2 cmentarzyska ciatopalne z wczesnej epoki żelaza (Collectio Archaeologica Ressoviensis, t. 21). Rzeszów: Fundacja Rzeszowskiego Ośrodka Archeologicznego.

Trybała-Zawiślak, K.

2019 Wczesna epoka żelaza na terenie Polski południowo-wschodniej-dynamika zmian i relacje kulturowe. Rzeszów: Wydawnictwo Uniwersytetu Rzeszowskiego. 


\title{
APPLICATION OF THE CORRESPONDENCE ANALYSIS TO THE CLASSIFICATION OF MATERIALS FROM THE LATER BRONZE AGE ON THE EXAMPLE OF FUNERAL INVENTORY FROM SOUTH-EAST POLAND
}

\author{
S u m m ary
}

For archaeology, chronology is an extremely important topic. Proper timing of events is essential to understanding the cultural changes taking place in prehistory. In the case of the Tarnobrzeg variant of the urnfield culture (hereinafter TLC - Tarnobrzeg Lusatian culture. It is a specific term for researchers from the south-eastern Poland used to define a local group from the circle of urnfields developing in the Wisłoka, Vistula and San rivers between the 13th and 13th centuries). 4th/3rd century BC). From the beginning of the separation of this cultural unit, discussions on its internal periodization continued. The first formal divisions were proposed by Kazimierz Moskwa and Marek Gedl. These were three-phase periodization systems. By indicating the material determinants (ceramic and metal materials) of subsequent phases, they attempted to define external influences (numerous monuments of eastern provenance in the third stage of the TLC development) and internal processes, such as changes in the funeral rite (skeletal graves in the early stage of TLC development). The above divisions were questioned by Bogusław Gediga during one of the conferences devoted to TLC. This researcher pointed out that the said patterns of development can be applied to each of the cultural phenomena (where each has its beginning, middle and end), but it is not a system that can be treated as an internal periodization of the development of this culture. A bit later, Jan Chochorowski proposed a division into three horizons $\mathrm{A}(\mathrm{BC} 2-\mathrm{BD}), \mathrm{B}(\mathrm{HaA} 2-\mathrm{HaB} 1)$ and $\mathrm{C}(\mathrm{HaB} 2-\mathrm{HaB} 3$ and intermediate materials A / B (HaA1) and $\mathrm{B} / \mathrm{C}(\mathrm{HaB} 1 / \mathrm{HaB} 2)$ for the earliest period of TLC development. According to this chronology, the middle period was supposed to fall on $\mathrm{HaB} 3$ and $\mathrm{HaC}$, and the late $\mathrm{HaD}$ and $\mathrm{LtB}$. Further research conducted on the cemeteries and TLC sediments allowed to clarify this system, among others the dating of TLC to BC2 was not confirmed. It was broken down into two sub-phases - the older one with Scythian materials and vases, and the younger one with egg-shaped pots. Materials from Grodzisk Dolna, site 1, Łańcut and Chodaczów district, site 2, were an important element in this discussion, which allowed for the traditional division of into smaller stages of the understood phase I. Dates C14 and stratigraphic analyzes of graves from Pysznica, state 1, Stalowa Wola district, gave rise to further refinements of the chronology.

Currently, based on the findings so far, the following division can be presented:

phase I - from the period BD / HaA1 to HaB3 (13 / 12-9th centuries BC), sub-phases A (I1) and $\mathrm{B}(\mathrm{I} 2-3)$ are separated here;

phase II - from $\mathrm{HaB} 3$ / HaC to $\mathrm{HaC}$ / D (end of the 9th-half of the 7th century BC);

phase III - from HaD to LtB / older pre-Roman period / (mid-7th-4th century BC), with two sub-phases III1 and III2.

Both for the 1st and 3rd phase, we can distinguish distinct sub-phases based on the differentiation of the style of the vessels. In their context, phase II appears more stylistically compact, in the case of which it is very difficult to notice any changes in forms or ornaments. It is quite commonly understood as a moment of a specific cultural regression and perceived through the prism of the "Nadsańska style", which has become its determinant. There are some premises that deny the indicated way of understanding phase II, e.g., the occurrence of a vase characteristic of the Nadsańska style, with the formal determinant of phase III, which is a nail-like earring in one of the graves in Obojna, poviat Stalowa Wola. The case of the cemetery in Pysznica is also important in this discussion, where the simultaneous occurrence of the "Nadsańska style" and "general Lusatian style" and 
their parallel development were documented. In view of the above, it would be a mistake to equate the "Nadsańska style" with the formal determinant of phase II. The vessels or decorative elements characteristic of this style also appear in phase III, although with a reduced frequency.

The terms "Nadsańska stylistics" used above and "general Lusatian stylistics" used in opposition to it need explanation. Both terms have been used in the literature for years, hence it does not make much sense to describe them accurately. However, it is worth recalling that these names were introduced by Sylwester Czopek in order to define larger sets of vessels with specific stylistic and values. The style of Nadsańska is usually defined through the prism of: vases and jugs from the Nadsańska as well as the so-called Zbydniowski bowls with very characteristic ornamentation. It is also worth quoting a work by Krzysztof Armian devoted entirely to this style. He divided the Nadsańska stylistics into 4 stages: proto-Nadsański (phase I1 in the development of TKE), pre-classical (phase I2-3), classical (phase II) and post-classical (beginning of phase III). In the case of materials from the classical phase, this division does not take into account any delamination, which means that the 200 -year-long phase is flattened. The problem of the youngest materials is also important, which confirm that this style is not a specific determinant of the phase in question, but only the dominant stylistic trend, which, although to a lesser extent, is also present in the next period.

The main aim of the paper was to check whether, by means of correspondence analysis, the materials of the traditionally understood phase II show formal differentiation, which may be the basis for separating smaller classification units of this style. This method allows for a graphic presentation of the relationship between the examined features. It should be emphasized that the analytical tool presented here was used in many works on periodization. This method has been used, among others in research on the diversity of the style of vessels from the Kietrz cemetery and in attempts to create systematics based on the variability of the stylistics of the ceramics of the Trzciniec culture, e.g., that originating from the territories of the Lesser Poland Upland and the areas of the San, Vistula and Wisłoka inter-rivers.

When concluding remarks on the subject of "Nadsańska stylistics", it should be noted that the materials associated with it occur in the territory limited to the northern part of the area occupied by the TLC. So far, 26 stands with ceramics made in this style have been documented in this area. Their cognitive value is very different (from single fragments of vessels to several hundred urns), therefore it was decided to limit the analysis to 3 necropolises, which contained the largest amount of materials. They include: Pysznica, Zbydniów site 1, area Stalowowolski and Furmany, site 1, area Tarnobrzeski. Materials from the 2 nd phase as well as the end of the 1 st and the beginning of the $3 \mathrm{rd}$ were found in these cemeteries. So it was a fully representative group.

\section{METHODOLOGY}

Correspondence analysis was the basic analytical tool used in the work below. Simply put, this method allows you to examine the relationship between specific features (the type of ashtray and its ornamentation) and the graves from which these items came. These data usually assume a cluster system. If the differences between the analyzed features are minimal, the algorithm groups the data into one cluster. In the case of a greater number of differences, the graphical presentation of data takes the form of multi-cluster. On the other hand, in the case of qualitative and quantitative distinctions (smaller or greater intensity of a given feature in the sets studied), the sinusoidal shape is. It is the most desirable form of the chart in all chronology studies, as it certifies the evolutionary changes taking place in the studied system.

The basic core of the source base for these analyzes was a collection of 610 grave inventories, in which the entire urn has been preserved. The study examined whether features such as the form of the ashtray, place, the way of ornamentation and the presence or absence of a cover had an impact 
on the differentiation. In the initial phase of the research, 201 variables were taken into account (71 types of urns, 75 features determining the ornamentation of the ashtrays, 35 types of covers, 17 features describing their ornamentation and 3 features for the chronology - whether the vessel was initially assigned to phase I, II or III). In the process of data encoding, we used the markings $0 / 1$, marking whether a given feature appeared (1) or not $(0)$.

The analyses were carried out in three stages. In the initial phase of the study, the entirety of the data was used, without omitting any of the features, to check how closely the three main stages of TLC development were. In the second stage, vessels with the "Nadsańska" and "general Lusatian" styles were put together. However, the "oldest" and "youngest" materials are not included in this list. This stage was to check whether the studied sets will form clearly separate clusters or whether groups of a mixed nature will arise. The last one focused on dishes with the "Nadsańska style". Lids and features that appeared in fewer than 3 burials were omitted. This stage is crucial to the problem at hand, because it was here that the materials were examined in terms of their internal diversity.

\section{ANALYSES OF SOURCES}

The graphical effect of the 1st stage analyzes is a graph that looks like a sinusoid. The vast majority of the examined features in this list are placed in its center (group II - 554 graves), while the arms (groups I and III) are less legible. Group I (23 vessels) represented the oldest materials (such as tulip-shaped pots) and separated quite well from the others. Group III ( 26 graves) are the youngest materials. The end of the axis undoubtedly groups the youngest elements of the TLC (like the entire surface roughened ovoid vessels with nodules and plastic slats). In the further part, we note the features that can be applied to the younger section of phase III (holes under the edge of the spout and a semicircular indentation). Next comes the materials that can be referred to the older part of the third phase and the turn of the second and third phase (CO2, 18 and 20, 27 and 29). In addition to the above, we also note materials of a mixed nature (containing the features of phase II and III). The above data was confronted with the $\mathrm{C} 14$ dates (14 dates from 11 graves), which confirmed that group III materials can be treated as chronologically the youngest. The other absolute age indications in this list are very similar. This state is illustrated by the difficulties in separating the materials of the 2nd and the beginning of the 3rd phase, signaled in the literature.

In the second stage of the analysis, which consisted in compiling materials with the "Nadsańska" and "general Lusatian" styles, we obtained 3 groups: A (42 graves), B (149 graves) and C (363 graves). In group A, mainly covers (most types of Zbydniów bowls), most often ornamented on the bottom (almost all ornamental elements) were noted. The ornamentation of ashtrays was limited to three elements: two horizontal grooves with diagonal engraved lines between them, a checkerboard motif and independent engraved zigzags, which most often separated the decorative elements. This group also included vessels with feet, which were characteristic of the cemetery in Zbydniów. The use of Zbydniów bowls of types 4, 5 and 6 as urns was also found. With the exception of WOŁ7, no type of ashtray was associated with this group. However, WND 1, 2, 3, 5, 7, 8, 10 appeared here, among which types 7 (9 vessels) and 10 (11 vessels) were the most popular. "General Lusatian" vases appeared only in single copies.

Group B is the most numerous and gathers all the elements and types of vessels in the Nadsańska style. Lids appear here sporadically and are usually not ornamented. In the case of "general Lusatian" vases, we can talk about the relationship of this group with the types WOE 4, 8, 13, 17, $18,21,22,27$. WOŁ4 (6 vessels), 13 (12 vessels) and 21 (10 vessels) appeared in a larger series of vessels. It should be noted, however, that the last of the listed ones (WOE 13 and 21) were also associated with group C. However, in this group we have ornamented vessels, while in C they were not decorated. Finally, it is worth mentioning WND 11, which was confirmed on 28 dishes. 
These were ashtrays decorated with a very impoverished Nadsańska style, limited to selected motifs, such as hatched triangles or wolf teeth. We should talk here about degenerate, post-classical forms, which, according to Sylwester Czopek, represent the youngest materials with the "Nadsańska style". It should also be noted that in the case of these vessels we register a similar situation as for WOE 13 and 21, the form of which seems to be specific to group C, but due to the ornamentation, these vessels were assigned to the group B.

The last group (group C) consists of "general Lusatian" vases of types 2, 3, 5, 6, 9, 11, 12, 13 , $14,15,17,20,24,25,26,29,30$. Mostly they refer to the end of the 2 nd and the beginning of the 3rd phase of the TLC development. As lids, semicircular and conical bowls were popular, which appeared in all types, most often in the form of MPK 4, which has no chronological value. Other forms of covers appearing in this set were ME 3 and 5, which can be referred to the end of the second and the beginning of the third phase of TLC development. As a rule, the dishes in this group were not decorated. This remark applies especially to WND.

Summarizing the above analyzes, it should be stated that materials from group B can more often be referred to the older sections of the second phase of TLC development, while materials from group $\mathrm{C}$ are usually the end of the second stage of the third phase. Sylwester Czopek used a very similar division in his work on the necropolis in Pysznica. In the older phase, we have materials with classic Nadsańska vases and dishes in the "general Lusatian" style from the older TLC development stage. In the younger one, there are materials with depleted Nadsańska vases and "general Lusatian" vessels. As for group A, it is difficult to assume that it is actually older or younger than group B. It seems that its difference resulted from adding to the list of lids, which led to the artificial separation of this group.

Unfortunately, it is not possible to verify the issues of the chronology of the groups presented above based on the results of the $\mathrm{C} 14$ analysis. We only have 5 dates, 4 of which are group B.

\section{ANALYZES ON THE "NADSAŃSKA STYLE"}

The previous two stages confirmed the observations made so far regarding the "Nadsańska style", including suggestions about its longer duration (at least until the $\mathrm{HaC} / \mathrm{D}$ ).

The last (third) stage of the analyzes concerns only the "Nadsańska stylistics". This study did not take into account other types of ashtrays, lids, as well as undecorated "Nadsańska" vases and rare ornamental motifs. In this aspect, the comprehensive data from all necropolises included in the analyzes does not show any major differences between the studied cases. Only examination of each of the cemeteries separately indicates the possibility of distinguishing certain stylistic phases.

Undoubtedly, the cemetery in Pysznica provides the most data. We managed to distinguish 3 groups: A (14 graves), B (67 graves) and C (32 graves). Group A stands out the worst (especially in relation to $B$ ), because the materials that make it up are few, which makes it difficult to talk about its relationship with a specific type of ashtray or decorative thread. It should be noted, however, that this is a group of vessels with the most extensive ornamental elements, the most popular of which are: the thread of wolf teeth in a straight arrangement and vertical engraved lines, between which there are horizontal grooves.

Compared to the above-characterized group A, group B is represented by a much larger series of vessels and stands out very well in relation to the cluster (group) C. We note here all types of urns and most decorative elements, but the decoration is slightly poorer, and the combinations of 3-4 elements. Undoubtedly, the most interesting is group C, dominated by WND 11 (21 vessels). We also note a significant depletion of decorative elements (usually 1-2 elements). Unfortunately, we are not able to confront the stylistic groups of ceramics separated on the basis of correspondence analysis with the absolute age markings. We only have three dates (two in group B and one in A), which do not differ significantly from each other. 
In the case of Furmany, 3 groups were obtained - A ( 8 graves), B ( 57 graves) and C (28 graves). In this case, group A showed a number of features in common with the analogous group in the cemetery in Pysznica (including the most richly ornamented vessels and the same leading styles). Another group B consists of richly ornamented vessels composed of even 5-6 elements. The dominant types of WND (7 and 10) can be indicated here. There is still group $\mathrm{C}$ and here, as in the case of Pysznica, we register the relationship with WND 11. The vessels were also relatively modestly decorated (1-2 elements).

The necropolis in Zbydniów remains to be discussed. In the case of this cemetery, almost all features were grouped in one cluster. Importantly, however, no WND 11 type vessels were recorded here. There is no, therefore, the main determinant of group C. It is also worth mentioning that generally the boundaries between particular groups are not very clear here. In the case of group A, the basis for distinguishing it was the ornament of wolves' teeth in a simple arrangement, which, however, also appeared in other groups. In the case of Zbydniów, this type of ornamentation, together with the vessels with feet, was placed at the beginning of the axis forming the discussed system, which may suggest a separate group. However, it is hard to see, possibly due to the small burst.

It seems that WND 11 was determined by the newest materials with the "Nadsańska style". In the case of the oldest materials, based on the results of our analyzes, it seems that they could be vessels decorated with wolf-tooth ornamentation in a straight arrangement and vertical lines separating decorative elements, as well as (only in the case of Zbydniów) vessels with feet on the bottom.

\section{SUMMARY}

Summing up, our considerations confirmed the earlier opinions about a clear border between I and II and a less clear turning point between the second and third phase of the TLC development. The analyzes carried out for the materials from the 2 nd and the beginning of the 3 rd phase also confirmed the observations of Sylwester Czopek for the cemetery in Pysznica, who distinguished two groups of materials for this necropolis. The first of the classic dishes with the "Nadsańska style" and the so-called "general Lusatian" vases, which should be related to the second phase of TLC development. And also the second one with materials with the impoverished "Nadsańska style" and "general Lusatian" vases referring to the beginning of the 3rd phase of the TLC development.

The most interesting analyzes turned out to be devoted exclusively to the "Nadsańska style". The individual approach to each of the cemeteries included in the study indicated several recurring elements that perhaps should be interpreted as specific trends. It can be seen that in this approach, the form of the ashtray (except for WND 11) had no chronological significance, the type of ornament was more important. Nevertheless - what seems important - certain forms of WND were more strongly associated with specific cemeteries. Unfortunately, it was these relations that distorted the image of the analyzes and led to the artificial joining of materials. For Pysznica and Furmany, the rhythm of changes was similar, while in the case of Zbydniów, we note almost exclusively materials from group B, which suggests a very narrow time frame in which the cemetery in Zbydniów would develop. These findings were also in line with the current state of knowledge. It is known that the cemetery in Furmany represented the oldest materials and developed until the beginning of the 3rd phase of TLC development. Zbydniów was supposed to develop from the end of the 1st phase through the entire 2 nd phase, but there are no materials for the 3 rd phase. The youngest was to be the necropolis in Pysznica, however, and here materials from the first phase appeared. From this perspective, the obtained image with a compact cluster in Zbydniów and the distinctive groups in Pysznica and Furmany becomes clear to us. 
In summary, the following conclusions and further research postulates can be made:

- The analyzes with the use of the correspondence table have confirmed the previous findings and conclusions, pointing to the correctness of the postulates to extend the duration of the second phase of the TLC development.

- These studies have shown that with comprehensive analyzes we can obtain "only" general trends, that is, a division into traditionally understood phases I, II and III. Only the separation of materials into specific cemeteries and focusing on one phase of development provide the basis for wider analyzes, which in turn shows that the rhythm of changes in different cemeteries could have been slightly different (some element could have appeared earlier or a specific form of the ashtray was the guiding principle).

- Although it was possible to identify materials that probably represented the oldest and youngest stages of the "Nadsańska stylistics", the lack of C14 dates makes it impossible to confirm these conclusions. It would be advisable to make consecutive $\mathrm{C} 14$ dates for graves that could represent the youngest and oldest materials in order to verify these results.

Despite the possibility of separating certain styles, most probably related to the younger and older period of development of the "Nadsańska style", the vast majority of materials form a compact group. Which, unfortunately, shows that we are still not able to fully explain the problems of the second phase of TLC development. 